\title{
TWO GLASS BOTTLES "CASE BOTTLE" FROM MUGHAL ERA AT TAREQ RAJAB MUSEUM, KUWAIT "STUDY AND FIRST PUBLISHED"
}

\author{
Sameh EL-BANNA \\ Archaeology Dep., Faculty of Arts, Assiut University, Egypt, \\ E.mail: drsameh1@hotmail.com
}

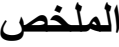

\begin{abstract}
This paper aims to study and publish two glass bottles known as the 'case bottle' from the Indian Mughal era (932-1237 H /1526-1858) to identify the name of this type, their use, the techniques and place of production. Both are part of the collection of Tareq Rajab Museum in Kuwait. The study also addresses the artistic features of the scenes and the decorative elements on the two bottles. It highlights the similarities and differences between the two bottles and other bottles from the same type, which are published or kept in public museums and private collections.

The paper addresses the subject through an introduction and five sections: Section 1: A descriptive study of the two bottles. Section 2: A study of the name and uses of the two bottles. Section 3: The production technique and the production centre for the two bottles. Section 4: Content analysis of the artistic features of the scenes and decorative elements on the two bottles. Section 5: A comparative study between the two bottles and other bottles from the same type that are published/ kept in other public museums and private collections. The study ends up with a conclusion detailing the results and an appendix of figures and plates.
\end{abstract}

\section{KEYWORDS}

Case bottle, Mould blown, Enamel, Gilding, Gujarat, Rajput paintings, Floral elements, Figural elements, Dutch coins.
تهدف هذه الدراسة إلى دراسة ونشر قنينتين زجاجيتين عرفتا

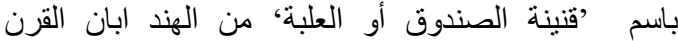

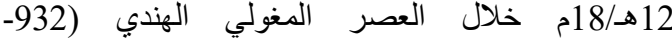

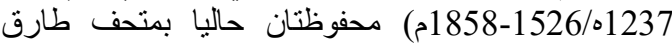

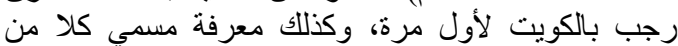

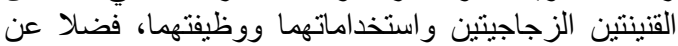

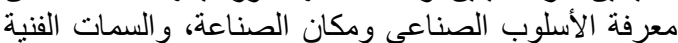

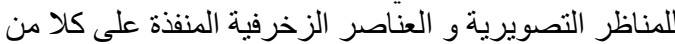

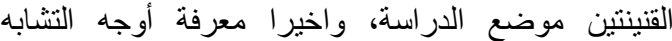

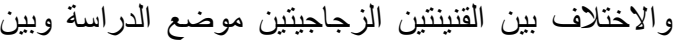

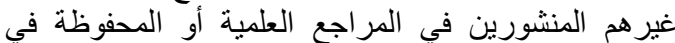

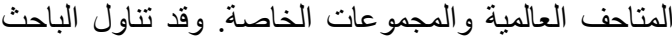

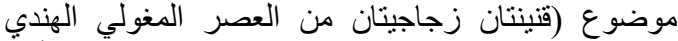

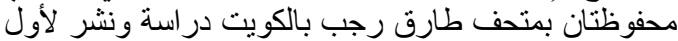
مرة) من خلال مقدمة وخمسة مباحث على على النحو التالي: لألئ المبحث الأول: الدراسة الوصفية الفنية للقتينتين الزجاجئ لإيتين

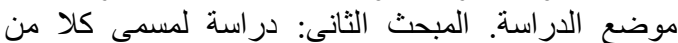

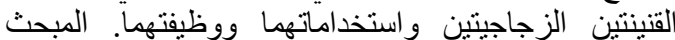

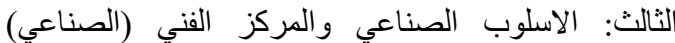

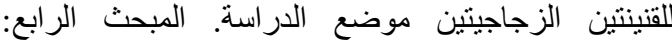

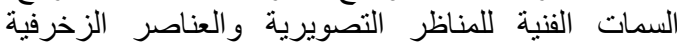

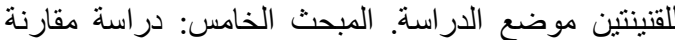

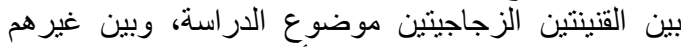

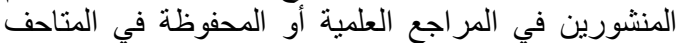

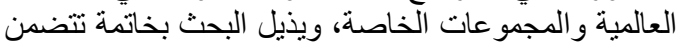
اهم نتائج البحث فضلا عن ملحق الأشكال و اللوحات.

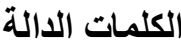

قتنينة الصندوق أو العلبة، النفخ في قالب، المينا، التذهيب، كجرات، مدرسة راجبوت، الزخارف النباتية، الزخارف النافينا،

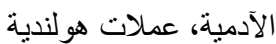

- 159 - SHEDET Issue nu. 6 (2019), pp. 159-188 


\section{INTRODUCTION}

India (especially during the Mughal era 932-1237 H /1526-1858AD) ${ }^{1}$ provided us with a huge number of artefacts made from different materials and with various ornaments and uses. Glass artefacts have a large share of this huge quantity, such as glass bases for hookahs ${ }^{2}$, glass pots, glass jugs and bottles of different sizes, shapes and functions. Some of these applied glass artefacts can only be attributed to India because of the large number of local decorative and industrial features associated with India. These glass artefacts are currently preserved in museums and private collections around the world, and some have also appeared in contemporary manuscripts. ${ }^{3}$ This is a documentary evidence of the importance of these tools for the Indian people; also some of these glass artefacts have a number of pictorial scenes that were similar to those in the manuscript. Amongst these Indian glass artefact stands a type of glass bottles known as the 'case bottle'.

This paper aims to study and publish two glass bottles from this type to identify the name of this type of bottles, their use, the techniques and place of production, both from the collection of Tareq Rajab Museum in Kuwait. ${ }^{4}$ The study also addresses the artistic features of the scenes and the decorative elements on the two bottles and compares the two bottles and others from the same type which are published or kept in international museums and private collections.

The paper addresses the subject through an introduction and five sections: 1) A descriptive study of the two bottles, 2) a study of the name and uses of the two bottles, 3) the production technique and the production centre for the two bottles, 4) content analysis of the artistic features of the scenes and decorative elements on the two bottles, and 5) a comparative study between the two bottles and other bottles from the same type that are published/ kept in other public museums and private collections. The study ends up with a conclusion detailing the results and an appendix of figures and plates.

\section{SECTION 1: A DESCRIPTIVE STUDY OF TWO BOTTLES.}

\section{1-1 A descriptive study of the first bottle.}

Type: A glass bottle (case bottle) (plates: $3,4,5,6,7,8,9,10$ ).

Material: Enamelled glass, coloured and gilded.

Production centre: Europe or India, but it was definitely ornated in Gujarat. ${ }^{5}$

Date: 12 th $\mathrm{AH} / 18^{\text {th }}$ century AD. ${ }^{6}$

\footnotetext{
${ }^{1}$ For more information about the Mughal Indian Empire see El-Nemer,Tarīkhal-Islām fi al-Hind,p.2; alShayal, Tarīkh al- 'batīrah al-maghül, pp.7-8.

${ }^{2}$ Abd-Aldaym (N. M.), Dirasah liqa' ìdat Narjilh hin̄̄dīya, pp.751,789.

${ }^{3}$ The Indian Mughal artists excelled in the drawing of applied artefacts, buildings and architectural elements in paintings; although they did not use geometrical tools, they performed with great skill. Munaa (S.A. H.), fannanūn fì marasīm 'bätarah almaghül fì al-hind, pp.24-25.

${ }^{4}$ The researcher submitted a request to publish and study the two bottles under study, to Dr. Ziad Tarek Rajab, Director of Tareq Rajab Museum. Dr. Ziad Tareq Rajab agreed with an official letter to the researcher's request to publish and study the two pieces for the first time. The researcher goes here with more thanks and appreciation to the officials of Tareq Rajab Museum for their assistance, especially the Director of the museum, Dr. Ziad Tarek Rajab, and Mr. Saif Adly Fayez, reception, communication and security officer, and communication with the museum, because they have both contacted the researcher and provided him with research information.

${ }^{5}$ Gujarat is a state on the western coast of India; it is bordered by Sindh to the north, the Arabian Sea to the south and west, and Malwa state from the east. Al-Gawarna, Al-hind fí zīl alwīlaya al-īsalmīyia, p.71
} 
Dimensions: Height: $12.5 \mathrm{~cm}$; width: $8 \mathrm{~cm}$; neck height: $1 \mathrm{~cm}$; neck width: $2 \mathrm{~cm}$.

Place and object number: kept at section 2- Tareq Rajab Museum in Kuwait, ${ }^{7}$ (Pls.1,2), with no registration number.
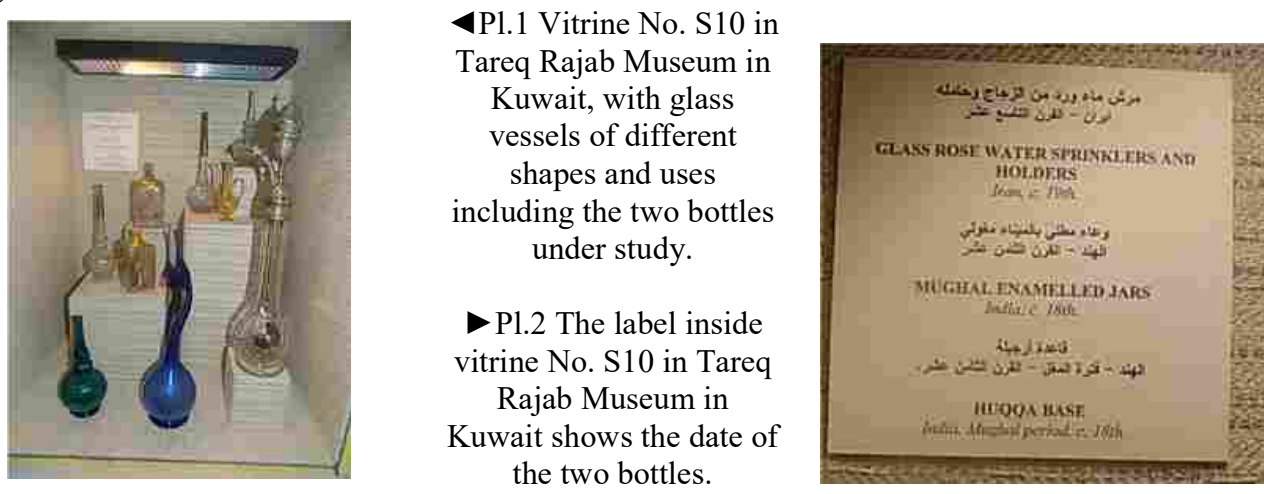

\section{Description:}

The first bottle has a cuboid body with a square base, and a cylinder-shaped neck which is $1 \mathrm{~cm}$ in height and stems from the middle of the upper part of the body. It is currently covered with a wooden stopper. The body is ornamented with enamelled, multicoloured and gilded elements. The first and third sides are decorated with human figures similar in style to the Indian painting school of the time. The other two sides are decorated with floral elements.

\section{The first side: (Pls.3, 4 - Fig.1)}

The first side is decorated with a scene representing two human figures on a background of gilded floral elements, taking the shape of branches with leaves of different shapes, especially five petal leaves. The first human figure is a lady in a sitting position, wearing the local traditional garment which consists of two pieces. The first, yellow, is known as choli ${ }^{8}$, while the second white one with a green middle is a Lehenga. ${ }^{9}$ She wears yellow shoes also. The carpet is blue with two borders, with a yellow outer one, and light pink inner. Her face is in profile $^{10}$ and she has long black hair. She is wearing several accessories (earrings, necklace with pendant and two bracelets). ${ }^{11}$

\footnotetext{
${ }^{6}$ This is the date on the general information label, the label contains basic information about glass artefacts in Vitrine S10 (Plate 2). The researcher believes the objects in this vitrine should be split between two vitrines.

7 The Museum was established in 1980, in Aljabereya, Kuwait. It displays a rare collection of Arabic manuscripts and some Islamic pottery, musical instruments and Arabic and Islamic furniture, jewelleries, accessories, ceramics and shields.

https://ar.wikipedia.org/wiki/\%D9\%85\%D8\%AA\%D8\%AD\%D9\%81 \%D8\%B7\%D8\%A7\%D8\%B1\%D9\%82 $\% \mathrm{D} 8 \% \mathrm{~B} 1 \% \mathrm{D} 8 \% \mathrm{AC} \% \mathrm{D} 8 \% \mathrm{~A} 8$

The museum occupies two separate buildings, the first in Street No.5, the second in Street No.1. The second is named after the founder's wife 'Jehan'; most of the objects in this house are manuscripts, while the other house's collection contains various objects. http://trmkt.com/?page id=10.

${ }^{8}$ Choli: a small shirt that covers the chest area, with straps tied from the back, leaving both the back and belly naked. Biswas (A.), Indian Costumes, p.30. Al-Shawkī(A.), Tașwīr al-mar'ah fì al- madrasah al- hinddīya, p.355.

${ }^{9}$ Lehenga: an Indian traditional garment for women, is a form of full ankle-length skirt worn by women covering the lower part of the body, usually with a number of folds.Al-Shawkī (A.A.), Tașwīr al-mar'ah fĩ almadrasah al-maghūlia al- hinddīya, pp.355,356. Al-nahas (Sh.Y), Al-'zia'w al-hūlāi al-hindīaya fi 'sr 'batīrah al-maghūl, pp.82,88.

${ }^{10}$ The profile pose was common in the paintings of Rajput school, which could be an influence from the Indian myths. It may be associated to the practice of drawing an image of Buddha, and making his shadow appear on a 

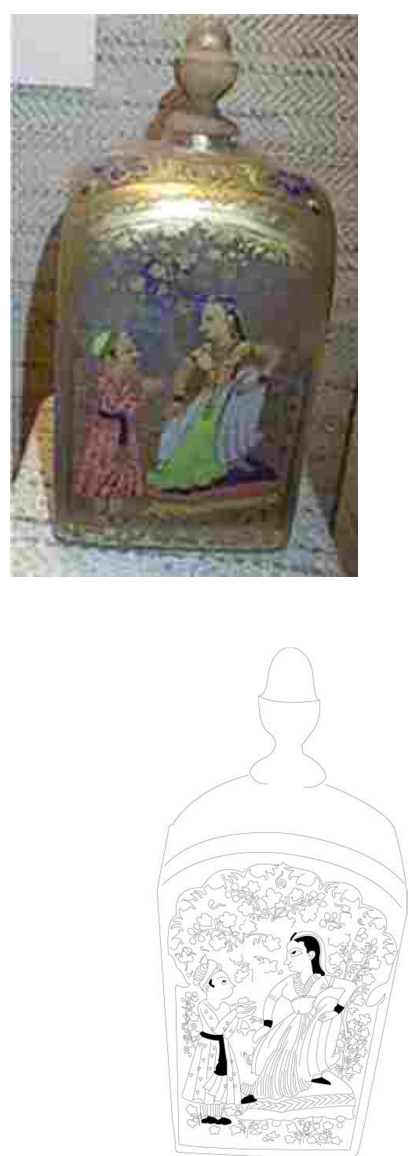

P1.3. The First side of the first glass bottle, preserved in vitrine S10, Tareq Rajab Museum in Kuwait, a scene of a man in front of a woman sitting on a rug. First publication.

P1.4: detail from the previous plate. First publication.

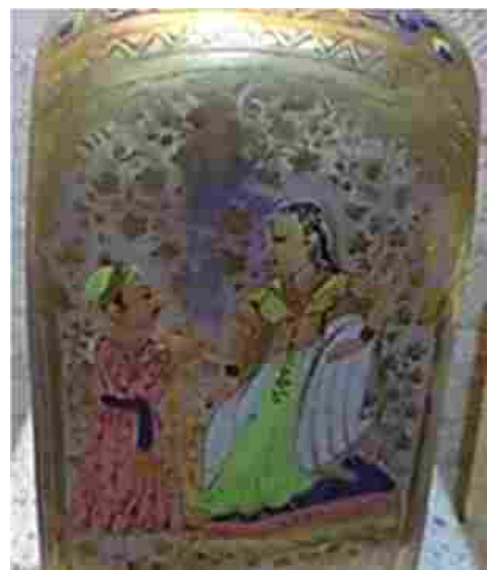

Fig. 1: Decoration of the first side of the first glass bottle preserved at the Museum of Tareq Rajab, Kuwait, showing a man in front of a woman sitting on a rug. Work of the researcher

Opposite to her, a man is standing in traditional Indian costume which is a knee length garment known as Jama; ${ }^{12}$ it is white and around the waist, a black belt ends with a tassel of golden threads. Under the garment there is a pair of white pants decorated with vertical black stripes. ${ }^{13}$ His head cover is a pointed-at-front green turban with a feather, and he wears golden coloured shoes. The man has a black moustache. The face is in profile also, with the right hand raised up. His movement indicates that he is speaking to the lady.

piece of textile in a profile pose; it then became a tradition in Indian art to use profile poses when drawing human figures. Men's faces were round and women's faces were rectangular with straight nose. Skin colour tends to be dark. Ghazaly, Madrasah Rachput fì al-tașwīr al-Hindī ,p.276. Mahir(S. M), AL-funūn alislamīya, p. 404. Hindawī (Rania U.), AL- 'nașir al- tașwīrīya, p.304.

${ }^{11}$ Bracelet: is a round piece of jewelries worn around the wrist. It is known in English as Bangel which is derived from the Indian word (Bangli) or (Bangri) which is defined as a bracelet for wrist or ankle. In India it was used as a kind of jewelry and it was considered a good omen for brides to wear large numbers of bracelets. During the Mughal Indian period, both men and women used to wear it, some of them made from glazed pottery, mother of pearls or metal, etc., in various shapes. Al-Nahas(Sh.Y.), Al-' zia' 'w al-hülāi al-hindīaya fi 'sr 'batīrah al-maghül.pp.246,256.

${ }^{12}$ One of the garments common during that period, is a knee length garment with long sleeves, worn by men, with a belt known as Batka usually around the waist, sometimes made of transparent cloth, and pants were usually worn under it. Brijbhushan (J.), The World of Indian Miniatures, p.114 Marzūq (A.M.), Madrasah kashmir fì Tṣawīr al-makhṭtat al-īslamīya, p.459. Al-Nahas(Sh.Y), AL-'zia' w al-hūlāi al-hindīaya fi 'sr 'batīrah al-maghül.p.52.

${ }^{13}$ A piece of clothing worn by men, women, or children under their other clothes, worn from the waist to the ankles, covering both legs separately. It was commonly worn by people from all walks of life. Marzūq(A.M), Madrasah kashmir fì Tṣawīr al-makhṭtat al-īslamīya, p.462. 
The scene is framed with a golden border, a thick line around the two sides and from blew, and an arch around the top. The two other bands are decorated with zigzag decoration (upper) and tri-lobe arches (lower).

\section{THE SECOND SIDE: (PIs. 5, 6 - Fig.2)}

This side is decorated with floral ornaments consisting of golden branches, with three leaves stemming from them; the outer part of each leaf is dark green and the rest is lighter. Above those green leaves, more leaves are stemming, with the outer line being dark red and the inside light red. The middle part of this side is busy with these red leaves, in addition to branches with two roses at the end. The most prominent among those roses is a large rose on the upper part of this side. The petals are similar to the red leaves present at the bottom of this side. This side is framed with a thick golden border, the upper part of which is a lobbed arch.

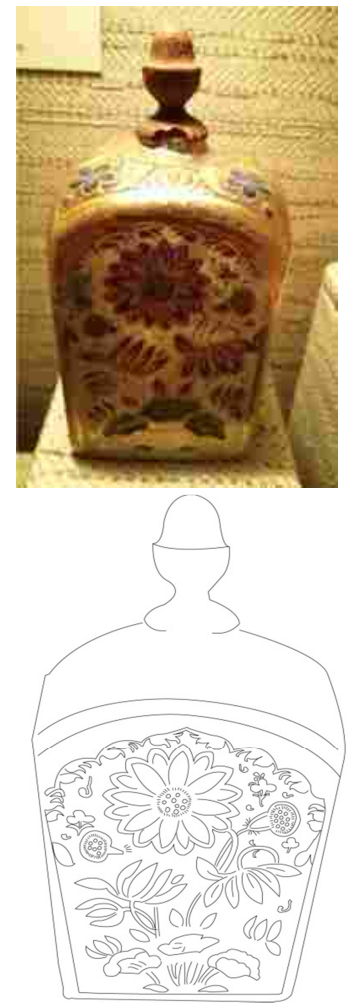

P1.5. The second side of the first glass bottle, preserved in vitrine $\mathrm{S} 10$, Tareq Rajab Museum in Kuwait, decorated with floral ornaments. First publication

P1. 6. Detail from the previous plate. First publication.

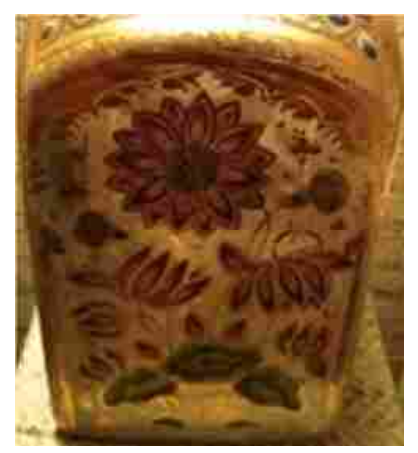

Fig. 2: The decoration of the second side of the first glass bottle preserved at the Museum of Tareq Rajab, Kuwait. This side is decorated with floral motifs.

Work of the researcher

\section{The third side: (Pls. 7,8 - Fig.3)}

Like the first side, a lady is seen sitting on a gilded chair, her face in profile and putting one of her right-hand fingers in her mouth, ${ }^{14}$ while her left rests on her left leg. The lady wears a blue garment and decorated her black hair ${ }^{15}$ with pearls and her forehead with a pendant

\footnotetext{
${ }^{14}$ Putting a finger in the mouth is a complex movement that reflects inner feelings. Ibrahim(K.A.A.), $\boldsymbol{L} \overline{\boldsymbol{u}} \boldsymbol{g} \boldsymbol{h} \overline{\boldsymbol{a}} \boldsymbol{t}$ al-Jasad fì al-qūrān al-karīm, p.79.

Klinton, Madlool Haraket AlGasad, p.6.

${ }^{15}$ Strings of beads, jewels, or links worn around the hair as an accessory were used by women during the Mughal Indian period. Hussein(M.I.), AL-Maraa Fi Intaj AL-Mūṣawīr al-muslim, pp. 40,41. Eisaa(M.M.), alMar'ah fì al-Tașwìr al-Maghülī, p.557. 
known as Tika. ${ }^{16}$ The background of the scene is floral, composed of gilded branches and leaves.

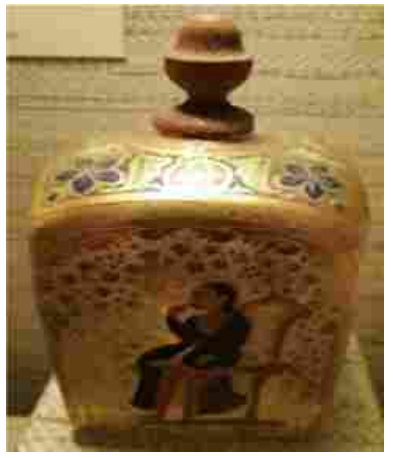

P1.7. The third side of the first glass bottle, preserved in vitrine S10, Tareq Rajab Museum in Kuwait, decorated with an Indian woman sitting on a chair and putting her finger in her mouth. First publication.

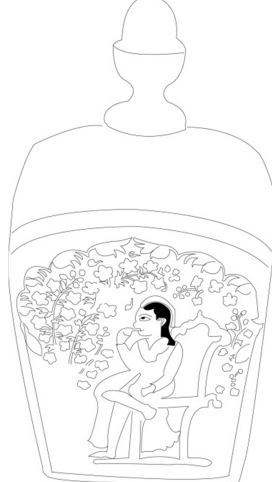

\section{The fourth side: (PI. 9)}
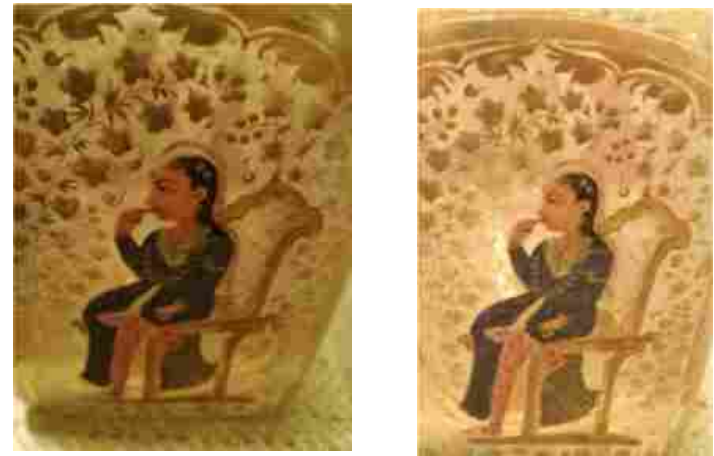

P1. 8. Detail from the previous plate. First publication.
Fig. 3

Decoration of the third side of the first glass bottle preserved in the Museum of Tareq Rajab, Kuwait. Work of the researcher

The fourth side is decorated with floral elements similar to those on the second side.

\section{The upper part: (PI.10)}

The upper part of the bottle refers to the neck of the bottle, and the rim, which is plugged with a wooden stopper. The four corners of the shoulder are decorated with a blue flower consisting of five petals with golden borders. Between the four flowers there are green leaves and pink flowers, all of them with the same golden trim.

\footnotetext{
${ }^{16}$ Tika or tilaka is a mark worn usually on the forehead, sometimes other parts of the body such as neck, hand or chest. Tilaka may be worn daily or for rites or special religious occasions only, depending on regional customs. It's a piece of jewel or attached to a metal chain or string of pearls. Haidar (Navina. N) \&Stewart (Courtney. A), Treasures From India-Jewels.p.74. AL-Nahas(Sh.Y.), AL-'zia' w al-hūlāi al-hindīaya fi 'sr 'batīrah al-maghül. p.143.
} 


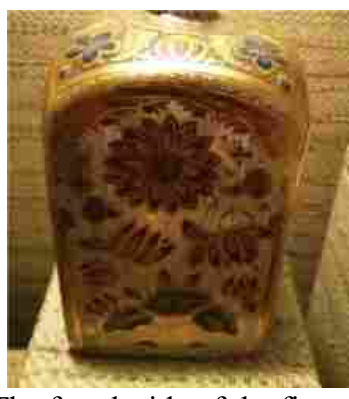

P1.9. The fourth side of the first glass bottle, preserved in vitrine S10, Tareq Rajab Museum in Kuwait, decorated with floral ornaments.

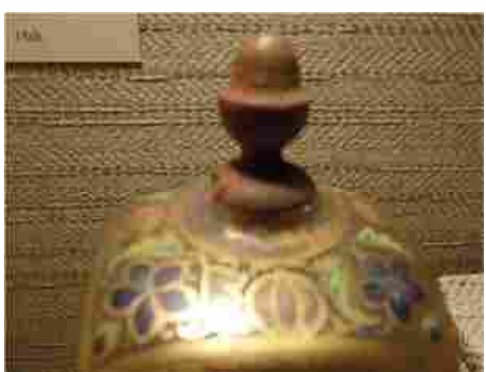

P1.10. The upper part of the first glass bottle, preserved in vitrine S10, Tareq Rajab Museum in Kuwait, decorated with floral ornaments and with a wooden stopper

\section{1-2 A descriptive study of the second bottle}

Type: A glass bottle (case bottle) (Pls. 11, 12, 13, 14, 15, 16, 17).

Material: Enamelled glass, coloured and gilded.

Production centre: Europe or India, but it was ornated in Gujarat.

Date: $12^{\text {th }} \mathrm{H} / 18^{\text {th }}$ century AD.

Dimensions: Height: $12 \mathrm{~cm}$; width: $6 \mathrm{~cm}$; neck's height: $2.5 \mathrm{~cm}$; neck's width: $2.5 \mathrm{~cm}$.

Place and object number: kept at section 2- Tareq Rajab Museum in Kuwait.

\section{Description:}

This bottle is similar to the other bottle in terms of shape. It has a cuboid body with square base and a short cylindrical neck at the top, but unlike the other bottle it has no wooden stopper. The body is similarly ornated with enamelled, multicoloured and gilded elements.

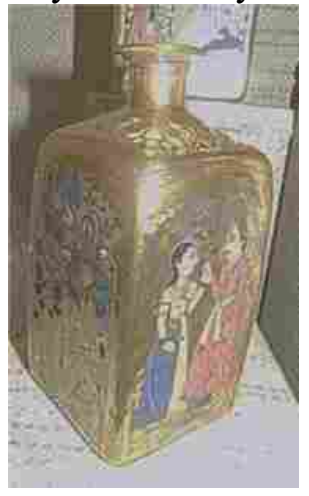

Pl.11. Two sides of the second glass bottle, preserved in vitrine S10, Tareq Rajab Museum in Kuwait, decorated with floral ornaments and human figures

\section{First Side: (Pls. 12, 13 \& Fig 4)}

This side is decorated with a scene showing a man and a woman in a romantic situation. The man holds the woman's left hand with his right. She wears the local traditional garment which consists of two pieces (choli, and lehenga). The woman's face is in profile, with wide eyes and long silky hair, and wearing a pearl on her nose ${ }^{17}$, two earrings, a red necklace, and two bracelets. Opposite her the man stands in traditional Indian costume, a knee length

17 Historians believe that nose jewellery became common in India by the $8^{\text {th }}$ century AD. It came with the Muslim conquest of Sindh, then became common during the Mughal period. In southern parts of India, it was popular to wear nose jewellery; some Muslim families put a small ring on which the name of a good Wali is engraved, on the nose of babies. For more information about nose jewelleries see: AL-Nahas(Sh.Y.), $\boldsymbol{A} \boldsymbol{L}^{-} \boldsymbol{z} \boldsymbol{z} \boldsymbol{i a}$ w al-hūlāi al-hindīaya fi 'sr 'batīrah al-maghül, pp.201: 207. Krishnan (Usha.R.B)\& Kumar(Meera S.),Dance Of The Peacock-Jewelry Traditions Of India.pp.175-177.

- 165 - DOI: 10.36816/shedet.006.09


garment known as a light pink Jama, and ornamented with floral elements. Around the waist he has a green belt with dark green tips. Under the garment he wears a pair of blue pants. His head cover is a pointed front green turban with a feather at its front, and he wears golden coloured shoes. In profile, the man has a black moustache, black eyebrows and with black hair locks around his ear. The way the man holds the lady's left hand, and the way they look at each other expresses romance. The background of the scene is a floral background, composed of gilded of stems, leaves and flowers. The scene is framed with a golden border, consisting of a thick line around the two sides and from blew, and an arch around the top. The two other decorative bands are zigzagged (upper) and a trilobe arch (lower), similarly to the previous bottle.

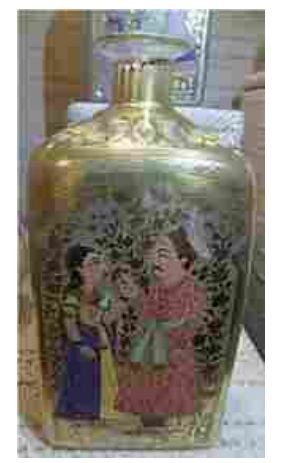

Pl.12. The first side of the second glass bottle, preserved in vitrine $\mathrm{S} 10$, Tareq Rajab Museum in Kuwait, decorated with a romantic scene showing a man and a woman.

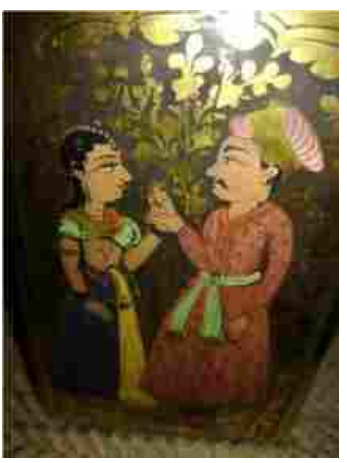

Pl.13 Detail from the previous plate

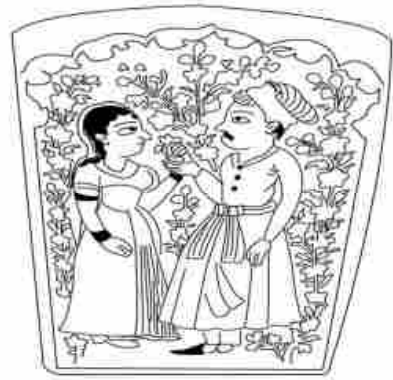

Fig.4: Decoration of the first side of the second glass bottle preserved in Tareq Rajab Museum in Kuwait.

\section{The second side: (Pl.14 \& Fig.5)}

This side is decorated with floral elements, stems and green leaves at the base; above those leaves, other stems end with three big flowers, with blue petals, golden borders and rose inner parts. The upper part is decorated with gilded stems and green leaves, from which gilded flowers grow. This side also has a thick golden frame.

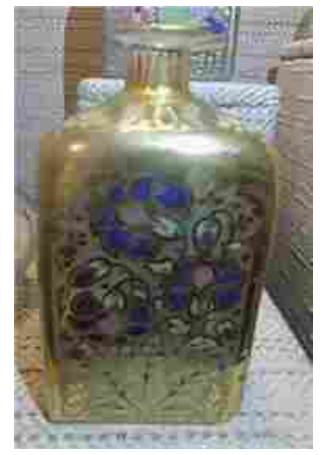

Pl.14. The second side of the second glass bottle, preserved in vitrine S10, Tareq Rajab Museum in Kuwait, decorated with floral ornaments.

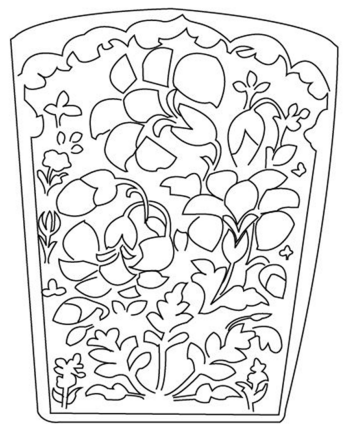

Fig. 5: The decorations of the second side of the second glass bottle preserved in Tareq Rajab Museum in Kuwait. 


\section{The third side: (Pls.15, 16 \& Fig.6)}

Like the first side, this side is decorated with human figures; a lady is sitting on a gilded chair with a green backrest. Her face is in profile and she is about to put one of her right hand fingers in her mouth, while her left hand rests on her left leg and her right leg is above the left one. She wears a blue garment and decorated her black hair with several pearls which is known as Tika. The background of the scene is a gilded floral one.
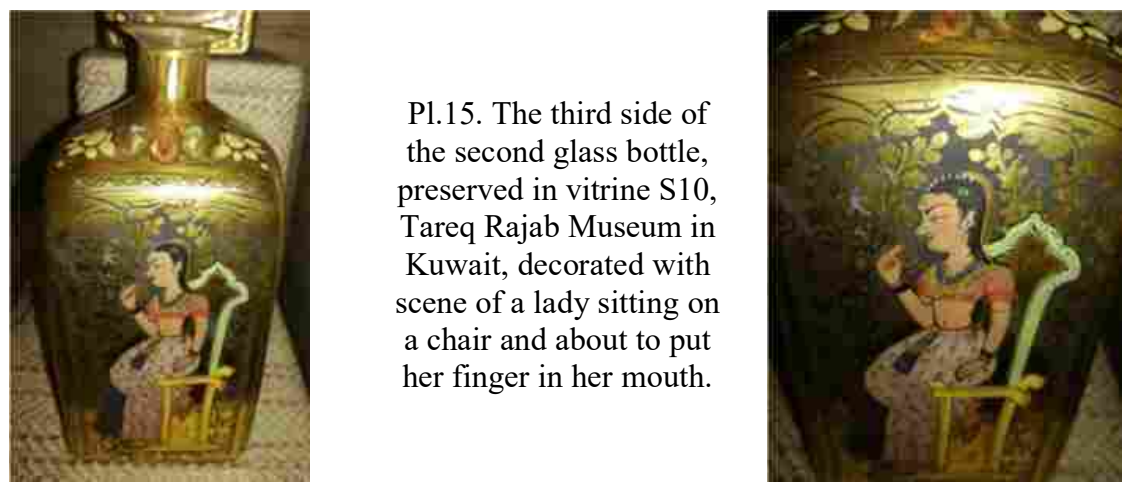

P1. 16. Detail from

Pl.15. The third side of the second glass bottle, preserved in vitrine $\mathrm{S} 10$, Tareq Rajab Museum in Kuwait, decorated with scene of a lady sitting on a chair and about to put her finger in her mouth.

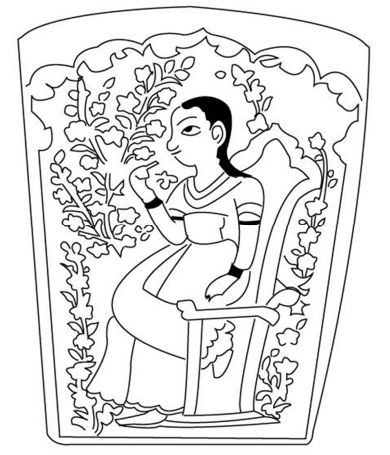

Fig.6: The decorations of the third side of the second glass bottle preserved in Tareq Rajab Museum in Kuwait.

The fourth side: (Pl.17)

The fourth side is ornated with floral elements identical to those on side two.

\section{The upper part: (Pl.18)}

The upper part of the bottle where the cylindrical neck stems from its middle, is $2.5 \mathrm{~cm}$ high. The four corners of the shoulder are decorated with a gilded flower consisting of five petals with golden borders. Between the four flowers there are green leaves and pink flowers, all with golden borders.

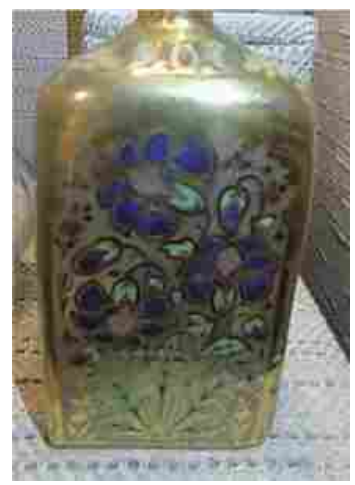

P1.17. The fourth side of the second glass bottle, preserved in vitrine S10, Tareq Rajab Museum in Kuwait, decorated with floral ornaments.

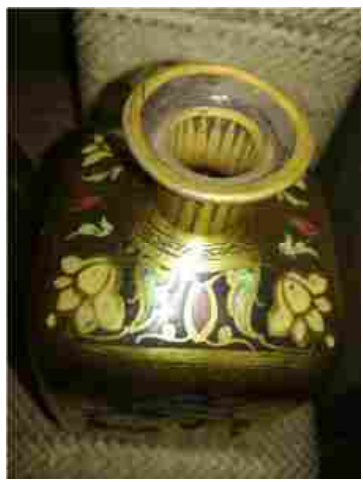

P1.18. The upper part of the second glass bottle, preserved in vitrine S10, Tareq Rajab Museum in Kuwait, decorated with floral ornaments. 


\section{SECTION 2: A STUDY OF THE NAME AND USES OF THE TWO BOTTLES}

Professor Jenkins Marilyn uses the term "Case Bottle" to refer to this type of object while studying a similar one in the Metropolitan Museum. In his opinion, gilding and enamel were among the most prevalent techniques of decoration during $12^{\text {th }} \mathrm{H} / 18^{\text {th }}$ century $\mathrm{AD}$, and the most common shape for the bottles was a square bottle called "case bottle". The name comes from the resemblance between this type of bottle and the bottles produced in Europe which were designed to fit in wooden transfer boxes. Many bottles of this type were manufactured in Europe and exported to India, ${ }^{18}$ where they were decorated. The same term was used by the curator of the Metropolitan museum; they used it in the main title in a label of one of this type of bottles, while in the description they used only the word "bottle. (Pl.19). ${ }^{19}$

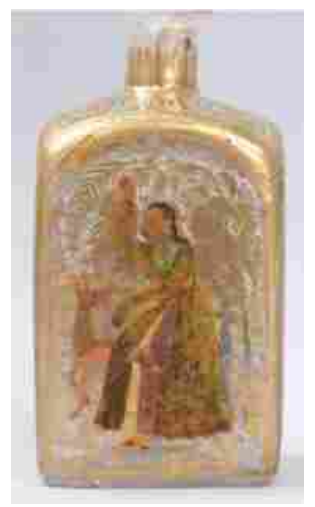

P1.19. Case bottle in enamelled and gilded glass, Metropolitan Museum in New York. Jenkins-Madina, Marilyn. "Islamic Glass: A Brief History." Metropolitan Museum of Art Bulletin vol. 44, no. 2 (Fall 1986). pp. $46-$ 47, fig. 51.

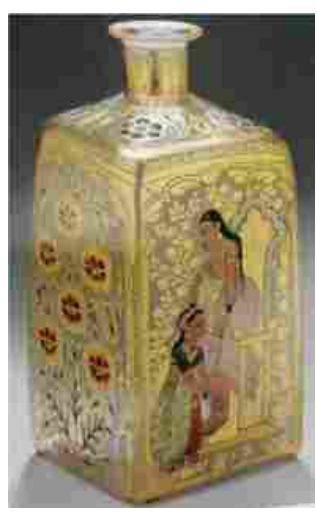

P1.20. Case bottle in enamelled and gilded glass, Los Angeles County Museum of Art, USA. Carboni, Glass in the Age of the Empires, pl.141.

In addition to Jenkins, Prof. Carboni used the same term (Case Bottle or Square Bottle) for this type of bottles which represents a large number of enamelled square bottles common in India during $12^{\text {th }} \mathrm{H} / 18^{\text {th }}$ century AD. Their shape is drived from that of the Dutch and German moulded glass bottles that date to the second half of the $11^{\text {th }} \mathrm{H} / 17^{\text {th }}$ century AD; they were known as Case bottle as they were kept in a box or a case. Also, the Dutch East India Company founded a commercial factory at Gujarat ${ }^{20}$ in 1618 , as Netherlands dominated Western India during the $11-12^{\text {th }} \mathrm{H} / 17-18^{\text {th }}$ centuries AD. ${ }^{21}$

Carboni also used the term "Square Bottle" or "Case Bottle" while describing two examples of this type, kept at the Los Angeles County Museum of Art (P1. 20). ${ }^{22}$

A small number of theses wooden cases or boxes used to transport this type of glass bottles have survived. At Corning Glass Museum, there is a small wooden box which is divided into four equal sections; each section has a square enamelled bottle inside, and a brass funnel is laid in the middle (Pl. 21). Another box at the Asian Civilization Museum in Singapore is a larger example similar to this one and it contains six bottles (P1. 22). The first box dates to

\footnotetext{
18 Jenkins, Islamic Glass: A Brief History, pp. 46-47, ill. fig. 51

${ }^{19}$ See website:

https://www.metmuseum.org/art/collection/search/447365?utm_source=pinterest\&utm_medium=pin\&utm_cam paign=loveboard

${ }^{20}$ Gujarat is known to be the melting pot of Indian cultures. Archaeological discoveries from the nearby site of Lothal date to 3000BC. Most towns in Gujarat were production centres for crafts, such as jewellery and clothes. Abd Al-Kareem(M.), Gujarat bawtakat al-thkafa al-hindīya, p.18. Tiromorti (T.S.), Wilayat Gujarat, p.25.

${ }^{21}$ Carboni(Stefano), Glass in the Age of the Empires, p. 287.

${ }^{22}$ Carboni(Stefano), Glass in the Age of the Empires, pp.286-287. \& see Cat.no140, 141.
} 
the $13^{\text {th }} \mathrm{H} / 19^{\text {th }}$ century $\mathrm{AD}$, while the second is earlier, dating to $12^{\text {th }} \mathrm{H} / 18^{\text {th }}$ century AD. This indicates that this type of bottles used to be produced in groups, each group consisting of four or six bottles, each group used to be in one of these boxes. At times, they were separated from their box, as seen in our study. ${ }^{23}$

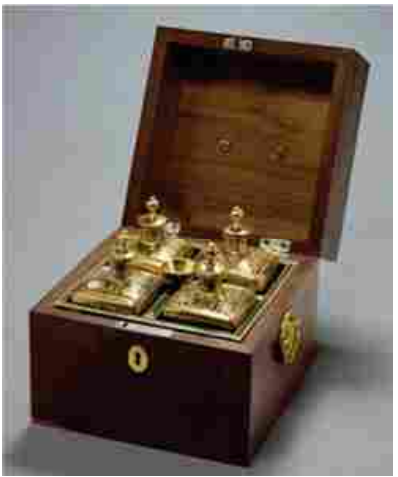

P1.21. 4 glass bottles in a wooden case, made in India or Europe, but decorated in India (1752-1750 AD). Corning Glass Museum (Source: Nancy Um, Nested Containers for Maritime Journeys, Fig.1

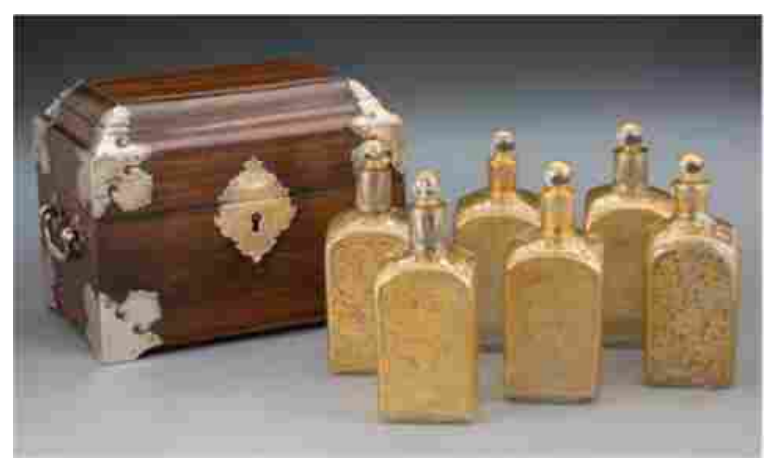

P1.22. 6 glass bottles \& a wooden case, made in India or Europe, but decorated in India (1752-1750 AD). Asian civilizations Museum in Singapore. Nancy Um, Nested Containers, Fig.3.

The type of small glass bottles studied here is similar to that manufactured in Europe during the $11^{\text {th }} \mathrm{H} / 17^{\text {th }}$ century AD that was kept or transported in wooden boxes/ cases thus; they are called 'case bottles', and were also called 'square bottle due to their square base. The term "rectangular prism bottle" should be favoured for this type of bottles, due to the three-dimensional body shape of the bottle.

Europeans produced bottles similar to the two studied ones, were produced in groups, each group contains 6 to 8 bottles. In European sets, these groups of bottles were kept in a case with cups, meaning that the set was used for drinking. On the other hand, in Mughal, this type of bottles was not accompanied by cups, suggesting that the bottles were used differently. It is possible that they contained beverages and some vessels were used for serving, ${ }^{24}$ or that they were destined to another purpose, perhaps to preserve liquids such as perfumes. The author favours the latter explanation as India had a reputation for making perfumes, rose water and herbal oils. ${ }^{25}$ In addition, these bottles are similar to Japanese porcelain bottles that were also used for storing perfumes. ${ }^{26}$ The small size, the fine

${ }^{23}$ Um(Nancy), Nested Containers for Maritime Journeys, pp.199-223.

https://www.journals.uchicago.edu/toc/wes/current http://www.west86th.bgc.bard.edu/articles/nested-containers/\#easy-footnote-14

${ }^{24}$ Carboni (Stefano), Glass in the Age of the Empires, p. 276.

${ }^{25}$ The trade Indian perfume was originated from the bathtub of the Mughal empress Noor Jahan, as rose petals were crushed and mixed with water in the bathtub, left for hours before bath time. One morning, the empress realised that an oily substance was floating on the surface of her bath water. This was the discovery of the finest Indian perfume, which is rose perfume, a sort of alcohol-free perfume which contains roses and herbal extracts. Archaeological findings show that early dwellers of the Indian subcontinent kept and groomed flowers, then they started to extract aromatic oils from herbs and animal products by means of pressure, crushing, or distillation. This was an industrial activity as pots and pottery containers were found in the Sindh Valley, as well as cylindrical distillation tools made of brass, which is at least five thousand years old. Gobata, Akdam Sharikat al- 'tür $\boldsymbol{A L}$-Hindīya. https://aawsat.com/home/article/486106/\%D8\%A3\%D9\%82\%D8\%AF\%D9\%85${ }^{26} \mathrm{Um}(\mathrm{Nancy})$, Nested Containers for Maritime Journeys, pp.199-223 \&see note 6. 
decorations with romantic scenes and elegantly dressed human figures, all suggest that these objects were used as perfume containers. Finally, the funnel with the group of four bottles kept in the Corning Museum (Pl. 21) may indicate that the liquid in these bottles was poured into other vessels, and that many of these bottles were used to preserve perfumes.

\section{SECTION 3: THE TECHNIQUE AND THE PRODUCTION CENTRE FOR THE TWO BOTTLES}

There had been little contributions from India to the glass industry prior the advent of Islam, ${ }^{27}$ as the influence of Islamic art gradually appeared on glass artefacts during the Mughal control over India during the $10^{\text {th }} \mathrm{H} / 16^{\text {th }}$ century AD. Some historians indicate local glass production at the time, such as Abu Alfadl the historian of emperor Jalal Aladdin Akbar who mentioned gilded cups produced in Bihar, and the Italian missionary Glimens Toss who stated in 1699 that Gujarat was a centre of glass vessels production. ${ }^{28}$

However, except for scenes in manuscripts of the time, produced at the Delhi imperial court or that of the Deccan princes where the emperors, princes and nobles are seen using glass artefacts, it is unknown whether there existed glass production in India at the beginning of the Mughal rule. It is possible that most items were produced in Europe and only a few in Iran and India. Indeed, since the middle of the $10^{\text {th }} \mathrm{H} / 16^{\text {th }}$ century AD there had been a flow of European glass products into India, especially from Venice, Britain and Bohemia. ${ }^{29}$ The dependence on European glass products had gradually declined during the reign of Shah Jehan who patronised the glass industry. Only a few examples were found from this period which could date to the time before Aurangzeb. Most of the Mughal glass artefacts date to the $12-13^{\text {th }} \mathrm{H} / 18-19^{\text {th }}$ centuries $A D{ }^{30}$

Whether glass products during the $12-13^{\text {th }} \mathrm{H} / 18-19^{\text {th }}$ centuries AD were made in Europe or locally in India, the emperors imposed nevertheless their artistic taste on these products, as the decorative style reflects the local Indian taste. It is thus difficult to attribute them to Europe only, especially with the many Indian decorative elements present.

https://www.journals.uchicago.edu/toc/wes/current http://www.west86th.bgc.bard.edu/articles/nested-containers/\#easy-footnote-14

${ }^{27}$ It has been suggested that despite the evidence for glass industry in India dating to $1200 \mathrm{BC}$, especially the production of beads and bangles, that of large glass vessels started a long time later. This would be connected with the increasing European presence at the time in the Indian Subcontinent after 1500 AD. Um (Nancy), Nested Containers for Maritime Journeys, pp.199-223. https://www.journals.uchicago.edu/toc/wes/current

-Alok Kumar Kanungo, "Glass in India," Encyclopedia of the History of Science, Technology and Medicine in Non-Western Cultures, Alpha-G, part 7, ed. H. Selin (Dordrecht: Springer, 2008), p.1027.

${ }_{28}$ AL-Sawy(Ahmed), AL-Awanī w al- 'dawät al-zujajīya fi al-hind. https://www.alittihad.ae/article/62211/2014

${ }^{29}$ Bohemia in Latin and Böhmen in German is the westernmost and largest historical region of the Czech lands in the present-day Czech Republic. Bohemia had an area of 52,065 km2 (20,102 sq. mi) and today is home to approximately 6.5 million of the Czech Republic's 10.5 million inhabitants. Bohemia was bordered in the south by Upper and Lower Austria (both in Austria), in the west by Bavaria and in the north by Saxony and Lusatia (all in Germany), in the northeast by Silesia (in Poland), and in the east by Moravia (also part of the Czech Republic). The word Bohemian is equivalent to the work Czech in the Czech language.

https://ar.wikipedia.org/wiki/بو هيميا

${ }^{30} \mathrm{AL}-\mathrm{Sawy}(\mathrm{Ahmed}), \boldsymbol{A L}$-Awan̄̄ w al- 'dawāt al-zujajūya fì al-hind. https://www.alittihad.ae/article/62211/2014 
Part of the above-mentioned glass products are the case bottles which the study deals with two of them. The technique used to manufacture the square bottles was "blow moulding", implemented by inflating molten glass into two parts-moulds. ${ }^{31}$ According to Carboni this industrial technique is a European influence. ${ }^{32}$ It is worth mentioning that Muslim glassmakers used the blow moulding technique and created products more accurate in shape than when using the free-blown glass technique. ${ }^{33}$ Indeed, the artefacts tend to have thicker walls, with less irregularities and mishaps, allowing also the production of multi-dimensional shapes. ${ }^{34}$ Moulds were made of clay, metal, wood or stone. ${ }^{35}$

An argument among scholars exists regarding the production location where this type of bottles was made, whether in Europe or in an Indian centre, particularly in Gujarat. Dikshit argues that it is a Dutch product that was produced for the Indian market, on the basis of the resemblance with Dutch bottles. Moreover, some bottles used a Dutch coin as their stopper $(\mathrm{P} 1.23)^{36}$. Jenkins believes that these glass bottles were made in Europe but painted in India.

Where Jenkins believes that these glass bottles were made in Europe but were later painted and decorated in India. ${ }^{37}$

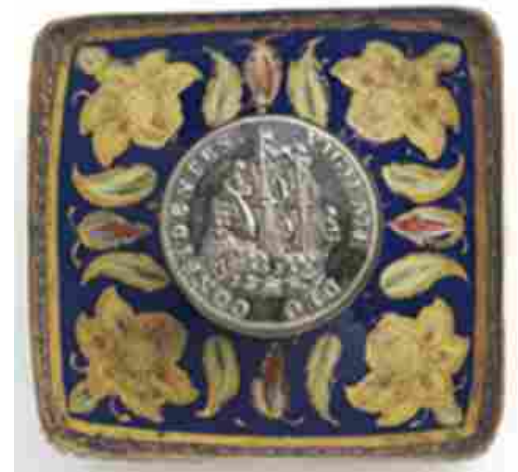

P1.23. A Dutch coin covers the rim of a square base glass bottle, enamelled and gilded. Victoria and Albert Museum, London. Nancy Um, Nested Containers, Fig.9.

Carboni is also in favour of this opinion but he insinuated from time to time that some of these bottles had been made in India using European, probably Dutch, moulds.

\footnotetext{
${ }^{31}$ There are two blowing techniques, the blow moulding one with wooden and multi-pieces' moulds, in order to obtain decorations covering most of the surface. The second technique is the free-blow technique; from the beginning of the $1^{\text {st }}$ century $\mathrm{AD}$ glassmakers using this new technique were able to create beautiful examples made of several bulges. Some believe that this technique was not an Egyptian innovation, as it was more popular in Phoenician towns. The two techniques have been used side by side for a long time. Zuhdi (Bashīr),

Lamha 'n al-zujaz al-qadìm W Rawa'au fì al-mothaf al-watanì bidīmishq, pp. 122,123,124,127. Daūūd(M.M.), al- mishkāwāt al- zujajīya, p.214,217. Mohamad(A.A.M.), Dirasah atharīya Fannīya Limagmu 'ah Jadida min al-zujaj, p.214.

${ }^{32}$ Carboni (Stefano), Glass in the Age of the Empires, pp.286-287.

${ }^{33}$ Abd AL-Khaliq(Hana'), Al-Zujaj AL-īslamī fi makhazīn wa matahif al-athar fi al-īraq, p.3.

${ }^{34}$ Abd AL-Latif(M.A.A.), al-zujaj al-Turkī, p.88. Mohamad(A.A.M.), Dirasah atharīyā Fannīya Limagmu 'ah Jadida min al-zujaj, p.214.

${ }^{35}$ Mohamad(A.A.M.), Dirasah atharīyā Fannīya Limagmu'ah Jadida min al-zujaj, p.214.

${ }^{36}$ Dikshit confirmed that European artists decorated these bottles in a way similar to the local ones in order to be popular on local markets. He backdated some of these bottles to 1725-1730, due to the existence of four bottles of this type, covered with Dutch coins, kept in the Victoria and Albert Museum. Dikshit, History of Indian Glass, p. 105. Um(Nancy), Nested Containers, pp.199-223. \& see fig.9. \& see notes 7-8 https://www.journals.uchicago.edu/toc/wes/current http://www.west86th.bgc.bard.edu/articles/nestedcontainers/\#easy-footnote-1

${ }^{37}$ Jenkins(Madina Marilyn),Islamic Glass:ABrief History,pp.46-47,fig51.

- 171 - DOI: $10.36816 /$ shedet.006.09
} 
Additionally, Carboni mentioned that a glassmaker in Gujarat, Ram Singh Malam, after spending time in Netherlands, opened a glass factory in Bhuj; his work was then patronised by Maharo Lakha (1741-1760), the director of a company in Kutch. Although it is hard to prove that Ram Singh Malam is the one who started the production of case bottles in India, his influence in the region must have been a contributing factor in the production of this type of bottles in Kutch and Gujarat. Markel also attributed these bottles to Kathiawar Peninsula in Gujarat during the second quarter of the $12^{\text {th }} \mathrm{H} / 18^{\text {th }}$ century $\mathrm{AD} .^{38}$

Even though Carboni mentioned that these square enamelled bottles were produced in India, especially in Kutch and Gujarat, he did not dismiss a partial production in Europe, nor deny the European influence in the moulds or the shape of the body. He did not exclude the idea that case bottles were exported from Europe and decorated in India, then sold on the local market. He also mentioned that chemical analysis of some square bottles indicate a strong relationship with Europe as the body contained alkaline, but at the same time he pointed out that glass bullions were imported from Europe and molten in India. ${ }^{39}$

In this study we support the hypothesis that these bottles were produced in Europe or India. The researcher believes that these bottles were decorated in India due to the decorative style, the gilding and enamelling techniques, as well as the similarity between the style used in scenes on the two bottles and that of the Indian painting schools. The researcher tends to share Carboni`s opinion that these two bottles were produced in India or Europe. ${ }^{40}$

Decorations on the two bottles which the study deals with, were implemented using gilding and enamelling techniques. Enamel was known in Greece in the $5^{\text {th }}$ century $\mathrm{BC}^{41}$. It was also used in ancient Egypt, as it was used for decorating a vessel belongs to King Tuhutmus III ( $18^{\text {th }}$ dynasty- $15^{\text {th }}$ century BC.). This vessel is kept in the british museum in London and it is the oldest known example of enameled glass. Muslims artists started enamelling during the $2^{\text {nd }} / 3^{\text {rd }} \mathrm{H} / 8^{\text {th }}-9^{\text {th }}$ centuries AD.century, and according to one of the greatest scholars in this field, they fully mastered the enamel technique and became pioneers in using it ${ }^{42}$

By the end of the $6^{\text {th }} \mathrm{H} / 12^{\text {th }}$ century $\mathrm{AD}$, the enamelling technique was common in the Levant. ${ }^{43}$ Raqqa is the oldest city known to have used the technique, then Damascus and

\footnotetext{
${ }^{38}$ Carboni (Stefano), Glass in the Age of the Empires, pp.286-287- 288.\& see Cat.no140, 141.

${ }^{39}$ Carboni (Stefano), Glass in the Age of the Empires, pp.276-288.

${ }^{40}$ Carboni (Stefano), Glass in the Age of the Empires, pp. 286 \& see Cat.no140, 141.

${ }^{41}$ Remenih Martine, Enamelling,step by step. Guish nash U.S.A, pp. 109-110.

Mohamad(A.A.M.), Dirasah atharīyā Fannīya Limagmu 'ah Jadida min al-zujaj, p.216.

${ }^{42}$ Carboni (Stefano), Oggetti, decorate di influsso islamico nella vetraria muranese, tecnica e forma, p.147. Mohamad(A.A.M.), Dirasah atharīyā Fannīya Limagmu'ah Jadida min al-zujaj, p.216.

${ }^{43}$ It is worth mentioning that Ward determined that the oldest dated example of enamelled glass bottles is the bottle kept in the Museum of Islamic Art in Cairo that bears the name of Saladin, believed to have been produced in Aleppo (1260-1273 AD) or in Damascus (1260-1273 AD). She also mentioned the existence of a nearly 30 -year gap in the production after this first example, with 3 bottles dating to the last quarter of the $13^{\text {th }}$ century. The first enamelled lantern was the one made for the Mausoleum of Amir Salar, dating to the period between 1303 AD when the mausoleum was completed and 1310 AD when Salar passed away. After that no enamelled glass was found in Rakka excavations, only tiles of faience and glass. She added that Al-Qazwini mentioned that in the third quarter of the $7^{\text {th }} \mathrm{H} / 13^{\text {th }}$ century $\mathrm{AD}$, an enamelled and gilded lantern was kept in the great mosque in Damascus.
} 
Aleppo where the technique was perfected. Enamelling reached its zenith during the Ayyubid and Mamluk eras $\left(6^{\text {th }}-9^{\text {th }} \mathrm{H} / 12^{\text {th }}-15^{\text {th }}\right.$ centuries AD).$^{44}$ Enamel technique kept being used in Iran even after the $12^{\text {th }} \mathrm{AH} / 18^{\text {th }} \mathrm{AD}$ century ${ }^{45}$. Europe learned this technique due to Muslim influences ${ }^{46}$, specifically on the Venetian glass during $9^{\text {th }}-10^{\text {th }} \mathrm{AH} / 15^{\text {th }}-16^{\text {th }} \mathrm{AD}$ Century. ${ }^{47}$ Both Iran which kept using enamel technique until the $12^{\text {th }} \mathrm{H} / 18^{\text {th }} \mathrm{AD}$, and Europe $^{48}$ conveyed this technique into India.

During the Mughal period (1556-1707 AD), Iranian glassmakers were brought to India and worked under the patronship of the Imperial court, as Iranian influences are seen in the Indian Mughal glass, in the decor but also in the technique, with the enamel, the use of coloured glass, and glazed designs. Also, Delhi and other local sites such as Kapavanj in Gujarat became important production centres. ${ }^{49}$ The resemblance between the Iranian and Indian Mughal glass supports the fact that some Muslim glass makers migrated from Iran to India at the end of the $10^{\text {th }} \mathrm{H} / 16^{\text {th }}$ century $\mathrm{AD} ;{ }^{50}$ based on this, the researcher is inclined to believe that the enamel technique moved from Iran into India with other industrial and decorative techniques.

In addition, starting mid- $10^{\text {th }} \mathrm{H} / 16^{\text {th }}$ century $\mathrm{AD}$, enamelled European products, especially from Venice, Bohemia ${ }^{51}$ and Great Britain were regularly imported into India. From the reign of Shah Jehan the dependence on European glass decreased due to the patronship he conferred to glass industry. A few examples of Indian glass artefacts can be attributed to the

Ward (Rachel), Glass and brass: parallels and puzzles,(Gilded and enameled glass from the middle east),British museum 1998,p.30\&see pls 9.1-9.5. EL-Banna(S.F.), 'Ihya' w muhakat al-qanadīl al-zujajā̄ya almamlūkīyīa, p.63.

${ }^{44}$ Mohamad (A.A.M.), Dirasah atharīyā Fannīya Limagmu 'ah Jadida min al-zujaj p.216.

${ }^{45}$ Farghaly (A. M), AL-Fūnun al-zūkhrūfīya fí 'sr al-ṣafawā̄n bī Iran, p.216. Mohamad (A.A.M.), Dirasah atharīya Fannīya Limagmu 'ah Jadida min al-zujaj p.216.

${ }^{46}$ Italian cities especially Venice, used to imitate Muslim mosques' lamps of enamelled glass during $9^{\text {th }} \mathrm{H} / 15^{\text {th }}$ century AD. There was a competition between Italian workshops and the Egyptian and Syrian ones, that led to the development of the production of enamelled glass mosque lamps in Italian cities, in France and also in Germany. By the end of the $9^{\text {th }} \mathrm{H} / 15^{\text {th }}$ century AD, the industry in Egypt had eroded, until it flourished again during the Ottoman era. Esaa(M.M.), Masterpiece of The Islamic Art, Glass Lamps From The Mamluk Period, p.89.

${ }^{47}$ Mohamad(A.A.M.), Dirasah atharīyā Fannīya Limagmu 'ah Jadida min al-zujaj, p.216.

${ }^{48}$ By the beginning of the $10^{\text {th }} \mathrm{H} / 16^{\text {th }}$ century $\mathrm{AD}$, the production of gilded and enamelled glass moved to Iran and Europe. Sources mention that in 977 H/1569 AD, the Grand Vizier Mohamed Pasha had requested the production of 900 enamelled lamps and 8 big lanterns from the Murano factory in Italy, the production of enamelled glass started also in China during the $9^{\text {th }} \mathrm{H} / 15^{\text {th }}$ century AD due to the active trade relationships between the far and near east. īsma îl (M.M.S.), Sin 'at al-zījäj fi Madināt al-Khalīl, p.46. AL-Esh(M.A.A.), al-zujaj AL-Sūrī al-Mumawwah bilmīna w al-dhahab, Vol 16, p.53.

${ }_{50}^{49}$ https://www.brit ( annica.com/art/Mughal-glass

${ }_{50}$ AL-Sawī (Ahmed) AL-Awan̄i w al-'dawāt al-zujajūya fì al-hind, Sina'h ìslamīya, https://www.alittihad.ae/article/62211/2014

${ }_{51}$ India was not the only country under Muslims control that used to import glass artefacts from Europe, as Ottoman Sultans also imported glass artefacts from Europe. At the beginning of their reign Ottomans were dependant on importing glass products from Venice and Bohemia (nowadays Czech Republic). Later the Ottomans established the first glass factory near Bicoz Village, with the founder of the factory being a darvish and glassmaker, Mohamad Dada. Marzūq (M.A) AL-funūn al- Zukhrufīya al-īslamīya, p.144. Nour(H.M.), Tuhaf zujajīya w aukhry ballorīya. p.41. Abbas(M.), Manarah al-Funūn Wa al-hadarah al-īslamīya, p.122.

- 173 - DOI: 10.36816/shedet.006.09 
reign of Aurangzeb, and most of Indian glass products date to the $12-13^{\text {th }} \mathrm{AH} / 18-19^{\text {th }}$ centuries $\mathrm{AD}^{52}$

Despite the presence of enamelled European products in India, the researcher suggests that enamel technique was transferred mainly from the Iranian craftsmen to their Indian counterparts, especially those who worked in Gujarat. The two bottles under study and other glass artefacts were decorated by Indians with their own artistic style. If we cannot determine the place of industry decisively, Europe or India, the enamelling technique and the decorations were made by Indian artists in Gujarat at the time.

Enamel is defined as a glazed, transparent or opaque glass substance, often coloured, composed mainly of sodium silicate and lead. Five elements are combined; glazing materials, the most important of which is silica; a smelting aid such as boric acid, a lead component; alkaline materials, especially compounds of sodium; coloured materials, such as oxides (iron oxides, copper, cobalt and manganese); dark materials to remove enamel's transparency (antimony and tin oxide). ${ }^{53}$ Also, enamel in metal artefacts ${ }^{54}$.

The second technique used on these two bottles is gilding, ${ }^{55}$ to paint some elements and to outline others. It is likely that this gilding technique was known in India thanks to the arrival of Iranian glassmakers and European glass artefacts.

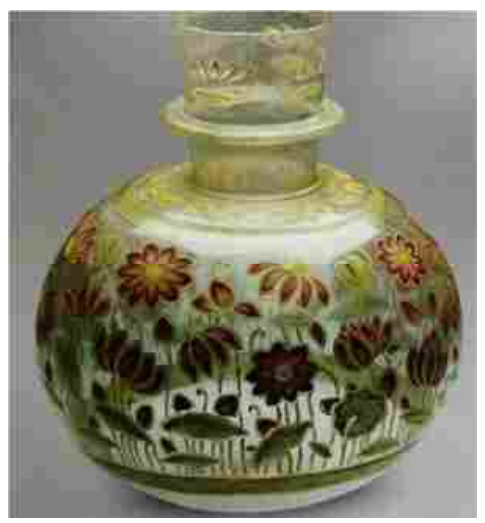

P1. 24. Hookah base in enamelled and gilded glass. Second half of $18^{\text {th }}$ century AD, probably produced in Lucknow, India. Los Angeles County Museum of Art. Carboni, Glass in the Age of the Empires, P1.137.

Apart from Gujarat, where we believe the production/ decoration of the two bottles took place during $12^{\text {th }} \mathrm{H} / 18^{\text {th }}$ century $\mathrm{AD}$, gilding and enamel techniques were used in other

\footnotetext{
${ }^{52}$ AL-Sawī (Ahmed), AL-Awanī w al- 'dawāt al-zujajīya fi al-hind https://www.alittihad.ae/article/62211/2014

${ }^{53}$ Abdullah (R.A.R) Dīrasah 'laj w sianah al-athar al-zujajīȳia al-mūzakhrafa bilmīna w al-Mumawwaha bildhahab. ìatbīkan ala majmo `at mothaf al-fan al-īslamī bil Qahira, pp. 30, 35,37.

54 It's worth mentioning that enamelling was used in decorating metal artefacts as well during the Indian Mughal period; brass and gold were enamelled with different colours (white, red, green, blue and turquoise blue). There are two ways to decorate metal with enamel, the cloisonné technique where flat wires are used to separate enamel, glass or jewels, and champlevé, where gaps are filled with coloured enamel. Zebrowski, Gold, Silver and Bronze from Mughal Indian, p. 263

${ }^{55}$ It should be noted that the method of gilding was known by the Egyptians before becoming a solution in the $4^{\text {th }}$ century BC. where it was proven that they were practising the manufacture of glass mosaic. Zuhdi (Bashīr), Lamha 'n al-zujaz al-qadīm W Rawa' 'au fì al-mothaf al-watanī bidīmishq, p.121.

The Romans invented the technique of throwing granules of ground gold in melted glass, while the shape was still hot. Byzantines also knew gilding as they used gold flakes on glass vessels, as seen on a bottle dating to the $9^{\text {th }}$ century AD, found in excavations at Samarra, attributed to Iraq or Iran production centres. Mohamad (A.A.M.), Dirasah atharīya Fann̄̄ya Limagmu 'ah Jadida min al-zujaj, pp.216,218.
} 
production centres such as Lucknow ${ }^{56}$ in Uttar Pradesh, where other types of glass artefacts were produced especially enamelled and gilded hookahs bases (P1.24) ${ }^{57}$

The gilding technique which was used in our two bottles from the same type, was widespread in India during the $12^{\text {th }} \mathrm{H} / 18^{\text {th }} \mathrm{AD}$. This technique was widespread for these bottles, but also on other types of glass artefacts, such as hookah bases. ${ }^{58}$ It is likely that the method used on the studied bottles is that of hot gilding. Commonly used from the $6-7^{\text {th }} \mathrm{H} /$ $12-13^{\text {th }}$ centuries $\mathrm{AD}$, this technique required using gold oxide with alkaline in the form of borax, as well as glue to be set on the surface of the glass vessel. It then entered the oven at a specific temperature to settle the mixture, and for the alkaline to fuse, forming a layer of glass, pasting gold on the glass surface of the vessel. This type of gilding is more stable, and was used in the Ottoman era. The second is the addition of gold solution as a coating on the places to be decorated, without creating an intermediate glazed layer, and without using the oven. Such gilding tends to disappear over time. This pattern of gilding was popular in the late $8-9^{\text {th }} \mathrm{H} / 14-15^{\text {th }}$ centuries $A D{ }^{59}$

\section{SECTION 4: THE ARTISTIC FEATURES OF THE SCENES AND DECORATIVE ELEMENTS ON THE TWO BOTTLES}

Many artistic schools appeared in India from the $10^{\text {th }} \mathrm{H} / 16^{\text {th }}$ century AD to the end of the $12^{\text {th }}$ $\mathrm{H} / 18^{\text {th }}$ century AD. The most important ones were the Mughal Indian School and some other local schools ${ }^{60}$ such as Deccan, ${ }^{61}$ and Rajput ${ }^{62}$ in Rajasthan in the north-western region. These schools share common features but each had distinctive characteristics; the Mughal

\footnotetext{
${ }^{56}$ Capital of Uttar Pradesh Province. Islam was introduced to this region by Ala Al-din Al-Khaljy in 708H/1309AD, and shortly after, Baber made it part of the Mughal empire. Sahai (Sorendra), Lucknow'ndama taqus al-'mara Tarīkh Madīna pp.19,20

${ }^{57}$ Carboni (Stefano), Glass in the Age of the Empires, p. 276 \& see pl.137 in p.283.

${ }^{58}$ Glass hookahs bases were decorated with multi coloured enamelled elements, with gilded outlines. One of the most important example is kept in Louvre Museum; a bell-shaped glass base, dates back to12th $\mathrm{AH} / 18^{\text {th }} \mathrm{AD}$, decorated with floral ornaments crowned with a clove flower, blue, green and purple enamel were used in addition to gilding._AL-Sawī (Ahmed), AL-Awanī w al- 'dawāt al-zujaj̄̄ya fí al-hind https://www.alittihad.ae/article/62211/2014

${ }^{59}$ Mohamad (A.A.M.), Dirasah atharīyā Fannīya Limagmu 'ah Jadida min al-zujaj, p. 218.

It is worth mentioning that while conducting microbiological examination on some gilded glass artefacts, on which the gilt was applied to cold glass, it turned out that a fungus of the type of Aspergillus characterized by the production of germs which have the ability to damage the bonding material and its properties.

Abdullah(R.A.R.), Dīrasah 'laj w sianah al-athar al-zujajīyīa al-mūzakhrafa bilmīna , pp.51,221,222

${ }^{60}$ Local Indian Painting schools flourished in Indian provinces and were known for their local styles. These schools existed before the Mughal era in India and continued alongside the Indian Mughal School which gave special interest to court scenes, while local schools used daily life scenes, Indian myths and nature scenes.

Perhaps one of the most important local schools is Rajput school. The early production of this school dates back to the end of the $10^{\text {th }}-11^{\text {th }} \mathrm{H} / 16^{\text {th }}-17^{\text {th }}$ centuries AD. There were also the Deccan school, which produced a large number of illustrated manuscripts over the period $10^{\text {th }}-11^{\text {th }} H / 16^{\text {th }}-17^{\text {th }}$ centuries AD; the Goller school, where artists migrated to during the first half of the $12^{\text {th }} \mathrm{H} / 18^{\text {th }}$ century AD; the Jammu school, which was part of the now Kashmir province, and became a big centre of art after Nadir Shah had conquered it in 1739 AD. Al-Muhr(R.S.A), Madaris al-tașwīr al-īslamī fi Iran w al-hind, pp. 221:231.

61 For more information about Deccan school see: AL-Shawki(A.A.), Madrasah al-Deccan fi al-tașwīr alIslāmī fĩ al-Fatrah (895-1098H/1490-1678AD), 2009, pp.20:80.

${ }^{62}$ Rajput school was known for depicting subjects form Indian myths and folklore. The art of painting had flourished during the period $10^{\text {th }}-13^{\text {th }} \mathrm{H} / 16^{\text {th }}-19^{\text {th }}$ centuries AD. A large number of paintings dates to that period and is kept in museums around the world. Ghazaly ('sra, M.M.), Madrasah Rajput fi al-tașwīr al-Hindī, p.z.

- 175 - DOI: 10.36816/shedet.006.09
} 
Indian School influenced other schools too. Examining the style of these bottles may indicate the origin and school of the artist's influence.

Carboni mentioned the existence of discrepancies in the style of decorative ornaments, which suggest that the bottles were decorated in various workshops in different territories, such as Ahmedabad, Surat, Bhuj and including Hyderabad in Sind. The drawing style on these bottles is similar to that used in contemporary miniatures of North West India, specifically Rajasthan, this style becoming widespread in Gujarat in the $12^{\text {th }} \mathrm{H} / 18^{\text {th }}$ century $\mathrm{AD} .^{63}$

In my opinion, the drawing style decorating the two studied bottles is similar to that of the Rajput School of painting. The artistic centres of this school were in the North West of India and close to Gujarat, where the bottles were decorated and perhaps shaped as well.

Carboni mentioned the similarity between the drawing style of the miniatures in Rajasthan and the paintings on case bottles, but he did not provide a detailed comparison. This study aims to establish this comparison, as many artistic elements reflect the strong influence of this school ${ }^{64}$ in the decoration of the two bottles.

The Rajasthan School was known for using dark colours, especially dark red and yellow, ${ }^{65}$ as well as a colour scheme based on different tones of basic colours (yellow, red, brown, green and blue). ${ }^{66}$ All these were used in decorating the two bottles; it is noticeable that these colours were generally favoured during the Mughal period as they decorated glass products and the miniatures of Rajput school, but were also used in decorating Mughal Indian carpets. $^{67}$

The artistic scenes common at this school of Rajasthan were related to religious books and myths, such as the love scene of Krishna and Radha, and scenes of Rajahs in different contexts, like hunting. In Jaipur, one of the artistic centres in Rajasthan, scenes were court scenes, love scenes in addition to portraits of Rajahs. In Buhari, yet another artistic centre of this school, the same mythical scenes appeared. There was an interest in this school for natural scenes which were used as background with trees and hills. ${ }^{68}$

Many of the scenes, especially the love one of Krishna and Radha, and the portraits of other people, are closely related to those depicted on the two bottles. This relation can be proven through scenes of the Rajput school, such as the love scene representing Krishna sitting with a lady under a banana tree. It dates to the $12^{\text {th }} \mathrm{H} / 18^{\text {th }}$ century AD and is kept in the Krannert Art Museum (Pl. 25). ${ }^{69}$ A painting from the Rajmala manuscript represents Kidar Rajimi and

\footnotetext{
${ }^{63}$ Carboni(Stefano), Glass in the Age of the Empires, pp.287 -288.

${ }^{64}$ Painting in Rajput can be divided into two sections; the production of Rajasthan school, which had centres in the North West of India such as Mewar, Bundi, Jaipur, Bikanir, Kishangar; and that of Bihar which had centres in Punjab mountains, such as Jammu, Bashholi, Kangra. Eisaa(M.M.), al-Mar'ah fĩ al-Tașwīr al-Maghūlī, pp.534,535.

${ }^{65}$ Ghazaly('sra, M.M.), Madrasah Rajput fĩ al-tașwīr al-Hindī, p.208.

${ }^{66}$ Sharma, (Lokesh Chandra), Abrief history to Indian painting,p. 71

${ }^{67}$ Red was one of the most important colours used in decorating Mughal Indian carpets. Yellow was used for the fields in carpets, the branches and floral bundles. Green was also used for floral leaves, scrolls, pointed leaves. Blue also was seen in floral leaves. Abd Al-Salam(M.A.), Al-sijjäd al-maghwūlì al-hindī, p. 301.

${ }^{68}$ Ghazaly(' sra, M.M.), Madrasah Rajput fĩ al-tașwīr al-Hindī, pp.208, 218

${ }^{69}$ Ghazaly(' sra, M.M.), Madrasah Rajput fĩ al-taṣwīr al-Hindī, Plate 20.
} 
dates to 1750-1675 AD (Los Angeles County Museum of Art) (P1.26). ${ }^{70} \mathrm{~A}$ painting represents Raja Sing looking at a girl in front of her house (British Museum) (Pl.27). ${ }^{71}$ Finally a painting represents a noble man with his beloved woman looking in a mirror $(\mathrm{P} 1.28) .^{72}$
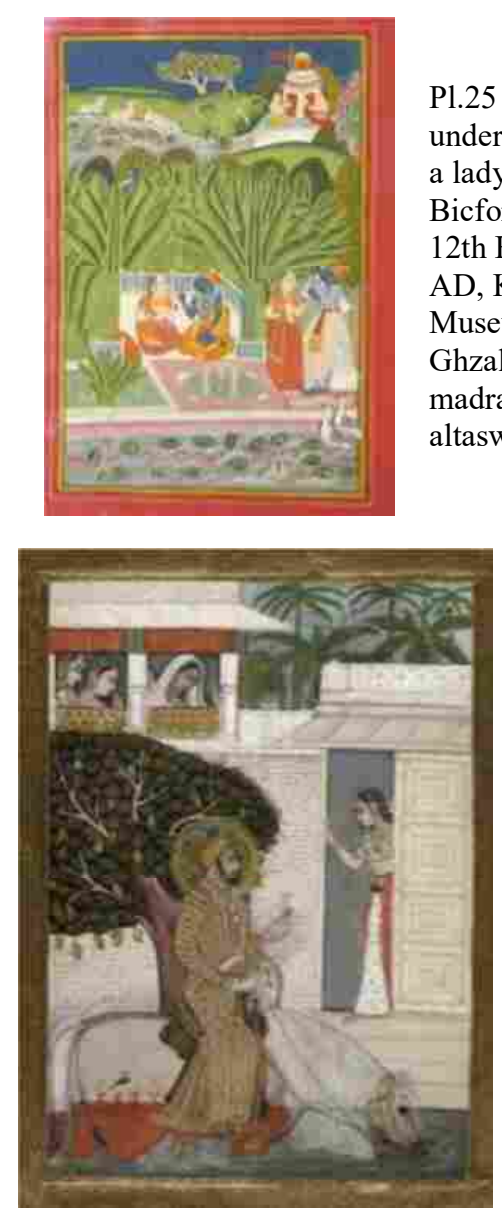

All these miniatures illustrate how love scenes and portraits were widespread in the Rajput school. In addition to that, the floral elements on the two bottles are similar to those seen in scenes of this school. For instance, a plate showing Krishna sitting with a lady under a banana tree (P1.25), and another Kidar Rajimy from the Rajmala manuscript (P1.26), both have floral elements similar to those decorating the second and fourth sides of the first studied bottle (Plates $5,6,9,10)$.

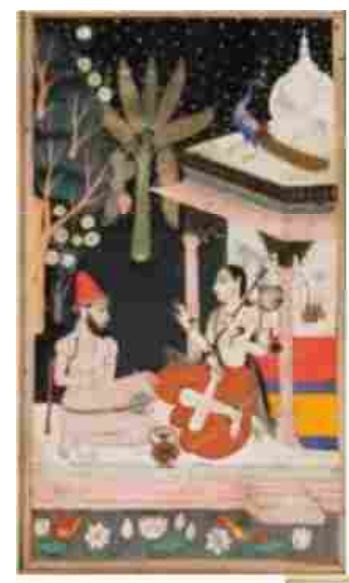

PI.26. An illustration from the Rajmala manuscript, representing Kidar Rajimi (1675-1750 AD). Los Angeles County Museum of Art. http://collections.lacma.o $\mathrm{rg} /$ node/249288
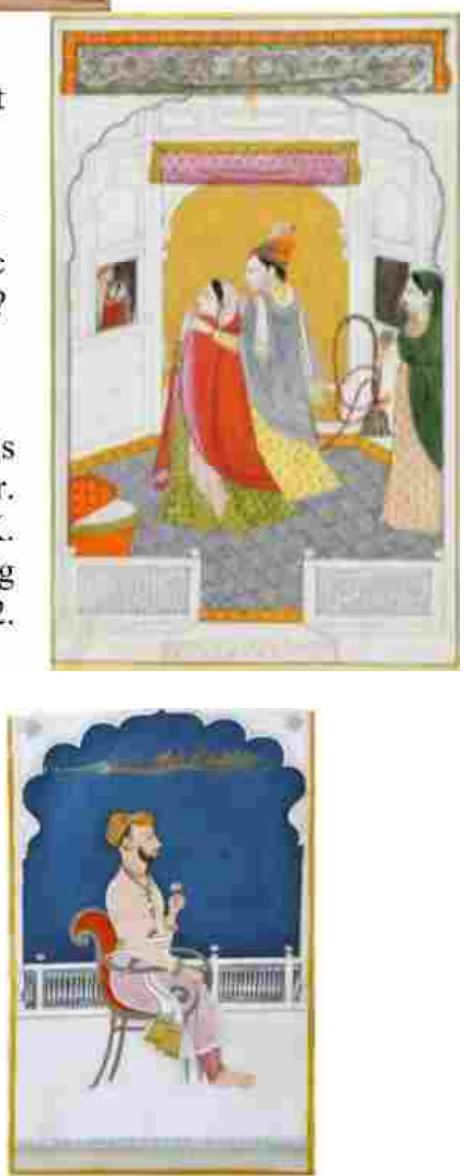

P1.29. from the George P.Bicford, kept in the Krannert Art Museum, Ghzaly( Isra'), madrasat rajbwt fa altaswir alhindii, P127

\footnotetext{
${ }^{70}$ http://collections.lacma.org/node/249288

71 http://www.britishmuseum.org/research/collection online/collection object details.aspx?

72 Losty(J.P.), Indian painting 1590-1880, P.48,pl.22. 
There is a likeness between portraits of this school and the human figures visible on our two bottles. A miniature from the George P. Bicford collection, kept in the Krannert Art Museum, dating to $1246 \mathrm{H} / 1830 \mathrm{AD}(\mathrm{Pl} .29)^{73}$ and representing a man on a chair, shows elements in this miniature similar to those seen previously, such as the golden frame, the lobbed arch and the type of the chair.

The above-mentioned miniatures from Rajput school were produced during 1700 - 1830 AD, at the same time than the two bottles were produced in Gujarat. It supports the idea that paintings from the Rajput school, specifically in Rajasthan, had an omnipotent effect on the execution of ornaments of the two enamelled glass bottles under study. The influence of the Rajput school was not confined to the subjects of the scenes, as it also affected the features of the human figures on the two bottles and other bottles from the same time.

It should be noted that the general aspects of the Rajput school included a mixture of local Indian heritage and some influences form the Mughal Indian school; the miniatures from this school reflect this combination. ${ }^{74}$ In the human figures in the early paintings produced in Mewar, the features of women were primitive and unbalanced. Later the features became finer, more delicate and proportionate due to the Mughal Indian painting influence after the year $1029 \mathrm{H} / 1620 \mathrm{AD}$. It was the same also in Bundi, as the paintings produced during the second half of the $11^{\text {th }} \mathrm{H} / 17^{\text {th }}$ century $\mathrm{AD}$, reflected influences from both the Deccan school and the Mughal Indian school due to strong relations with the Mughal Indian Empire. Faces were pale, especially during the $12^{\text {th }} \mathrm{H} / 18^{\text {th }}$ century $\mathrm{AD}$, women looked like men, with a pointy nose, fat chin and a big chest. Women in the paintings of Bundi school had different features in each painting; sometimes simple with dark skin, sometimes round, large forehead, pointy noses, small mouth and puffy cheeks, with a chubby and short body. ${ }^{75}$ It is noted that the drawn features of these women shown on some Rajput paintings attributed to the Rajasthan region (in particular, Mewar and Bundi) were seen in those of the women depicted on the two bottles under study. They were characterised by simplicity, pointy noses, prominent breasts, blown cheeks and short stature (Pls. 4, 8, 13, 16).

Clothes of men and women in the paintings of Rajput school are also very similar, being mainly local Indian traditional clothes. Men's clothes were composed of Jama (a knee length garment) and pants, a shawl and a middle size turban with upper part slightly bent at the back. Women's clothes were also mainly local Indian traditional clothes, choli and lehenga, but the Mughal Indian School is noticeable specifically in the long garment that covers their

\footnotetext{
${ }^{73}$ Ghazaly('sra, M.M.), Madrasah Rachput fí al-tașwīr al-Hindī, Plate 27.

${ }^{74}$ During the second half of $11^{\text {th }} \mathrm{H} / 17^{\text {th }}$ century $\mathrm{AD}$, the rulers of Rajput province joined the Indian Mughal state and held important positions in the Imperial court, becoming allies with the Mughal elite and marrying with them. Following the steps of Mughal, they employed artists to work at their courts, as some Mughal artists moved from the Imperial court to Rajasthan and other centres. These artists shared the Mughal influence which later merged with the local Indian styles and produced a new artistic style, characterising the school of Rajasthan. Chand, Rajasthan miniature painting a review, p.82

One of the marriages that contributed to transferring the influences between the Mughal school and Rajput school, was the marriage of Akbar and the daughter of the prince of Rajput; the ancient Indian style merged with the Islamic Mughal Indian styles. Zeenut (Ziad), The Magnificent Mughals, p. 63. Abd AL-Salam(M.A.) Al-sijjād al-maghwülī al-hindī, pp. 248, 349.

${ }^{75}$ Eisaa(M.M.), al-Mar'ah fĩ al-Taswīr al-Maghūlī, p.545. Ghazaly('sra, M.M.), Madrasah Rachput fĩ altaṣwīr al-Hindī, pp.210-211-213.
} 
whole body ${ }^{76}$ Apart from the human figures, the two bottles which the study deals with were decorated with floral and geometric ornaments. Floral ornaments occupied two sides and the top of the bottle. Indian artists were fond of floral decorations being influenced from the natural environment of the Indian subcontinent, which has many rivers and plenty of forests. They also were affected be Iranian influences, especially Safavid ones. ${ }^{77}$ It is known that Iranians preferred to use vegetal elements on other decorative elements. ${ }^{78}$ Floral motifs appeared on many applied artefacts dating to the Indian Mughal period. For instance, metal artefacts, including a metal betel box (pandan) preserved in the National Museum of New Delhi (Fig.7). The same can be seen on another metal box, which is preserved in the Ashmolean Museum in Oxford, and dates to the $11^{\text {th }} \mathrm{H} / 17^{\text {th }}$ century AD (P1.30) ${ }^{79}$ (Fig.8). ${ }^{80}$

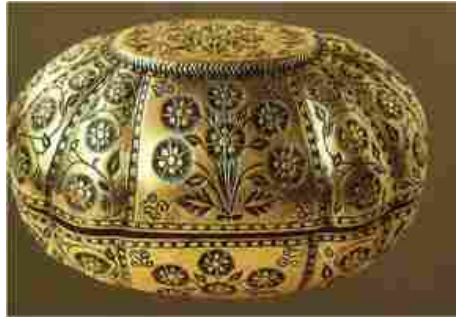

P1.30 Metal betel box, Ashmolean Museum, Oxford, $11^{\text {th }} \mathrm{H} / 17^{\text {th }}$ century AD. Zebrowski,, Gold, Silver and Bronze from Mughal Indian,274.

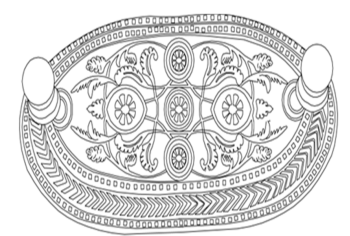

Fig. 7: A metal betel box $\left(12^{\text {th }} \mathrm{H} / 18^{\text {th }}\right.$ century $\left.A D\right)$, National Museum in New Delhi, El-Banna, Betel box, Fig 1b

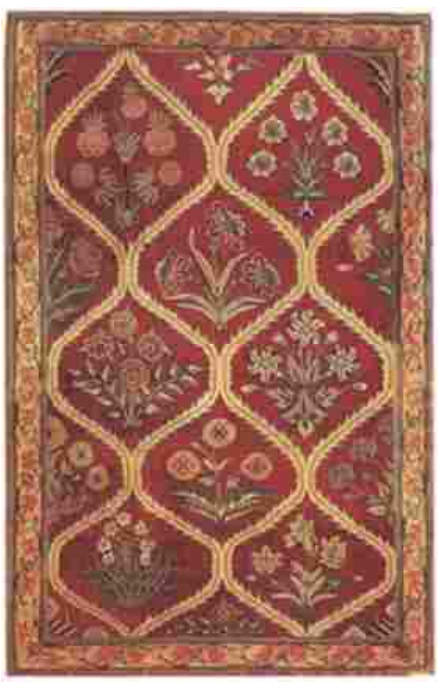

P1.31. A carpet kept in the Victoria and Albert Museum (11 ${ }^{\text {th }}$ $\mathrm{H} / 17^{\text {th }}$ century $\mathrm{AD}$ ). Ernst, The World Of Islam, pl.89.

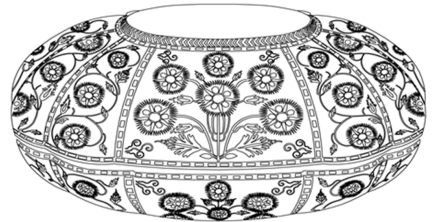

Fig. 8: A metal betel box $\left(11^{\text {th }} \mathrm{H} / 17^{\text {th }}\right.$ century AD), Ashmolean Museum, Oxford. El-Banna (Sameh), Betel box, Fig 2a

\footnotetext{
${ }^{76}$ Ghazaly,('sra, M.M.), Madrasah Rachput fĩ al-tașwīr al-Hindī, pp.211-212.

${ }^{77}$ Amina Okada mentioned that Iranian influences came to Indian arts since the Shah Tahmasp when Humayun moved and lived in the Safavid court. She also mentioned that Indian art was a combination of local influences and Safavid, Turkish and European ones. Okada (Amina),Indian Miniatures of the Mughal court,translated by: Deke Dusin Berre,Newyork,Harry N.Abrahms,Inc. Publishers,1992.p.11.

Abd AL-Salam(M.A.) Al-sijjäd al-maghwūlī al-hindī, p.387.

${ }_{78}^{78}$ El-Banna (S.F.), Betel box, pp.141-142-143.

${ }^{79}$ Zebrowski, Gold, Silver and Bronze from Mughal Indian, p. 274.

${ }^{80}$ El-Banna(S.F.), Betel box, fig 2a.
} 

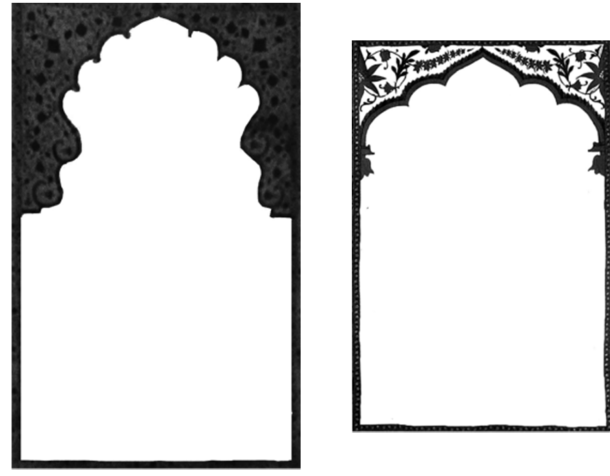

Fig.9. Detail of lobed arches encasing prayer niches from Indian Mughal prayer carpets. Abdul Salam, Al-sijjad ALmaghuly,
Prayer carpets were one of the most important Mughal Indian artefacts decorated with floral ornaments. Many were decorated with floral elements such as flowers and leaves, ${ }^{81}$ the artist cleverly filling large spaces and borders of carpets with floral ornaments. Such example is preserved at the Victoria and Albert Museum, dating to the $11^{\text {th }} \mathrm{H} / 17^{\text {th }}$ century AD (Pl. 31). Decorations were implemented using different techniques, and they were executed using realistic style especially in miniature of manuscripts ${ }^{82}$ in some cases and in a modified style in other cases with ability that reflects the innovation, variety and imagination. ${ }^{83}$

Finally, we point out the relation between the various floral ornaments and the purpose the bottles were used for, which is preserving perfumes and scents extracted from flowers and plants.

The geometric decorations on the two bottles had less importance than the floral elements and the scenes, as the zigzag pattern and the lobbed arches were concentrated in the frames. especially the frame with the zig zag decoration and the lobbed arches.

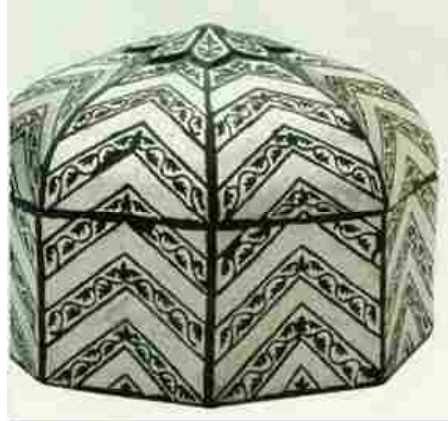

4 P1 32. Metal betel box (pandan), lid and base decorated with floral elements.

Zebrowski, Gold, Silver and Bronze from Mughal Indian, p.311.

- P1. 33. Bracelet (Pazoband), Victoria and Albert Museum in London, $12^{\text {th }} \mathrm{H} / 18^{\text {th }}$ century AD. http://collections.vam.ac.uk/item/0 69624/vanki-armlet-unknown.

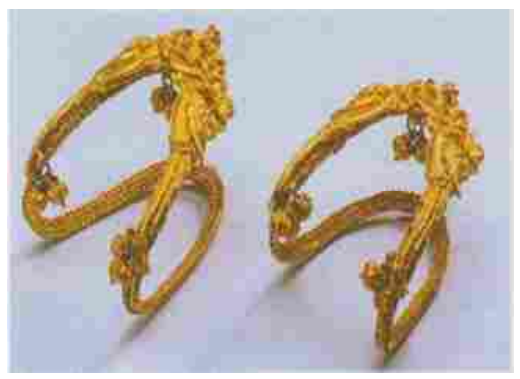

Zigzag frames appeared on Mughal metallic artefacts from the same period, especially pandan boxes, such as on the lid and base of an octagonal pandan box (Pl. 32), on another box in the form of a shell (New Delhi National Museum) for which the oval area on the top of the centre of the lid is outlined with frames, the middle one being decorated with chevrons (V shaped decorations) (Fig.7). ${ }^{84}$ Zigzag decorations also decorated a Pazobend, ${ }^{85} \mathrm{kept}$ in the

\footnotetext{
${ }^{81}$ Artists of the Indian Mughal carpets used floral leaves and multi petal flowers, in addition to wild hyacinth flowers, bell-shaped flowers, Chinese lotus and stems. Abd Al-Salam(M.A.), Al-sijjäad al-maghwūlī al-hindī, p.289.

${ }^{82}$ Various floral ornaments were used in decorating the Mughal Indian manuscripts, the best proof of the passion that Mughal emperors had for floral elements is a plate from the manuscript of 'Dara Shiko' which is kept in the Indian Office in London, where the prince 'Dara Shiko' is learning from specialised artists how to draw different shapes of flowers. Swarup (Shanti), Mughal Art -A study in Handicrafts, p.36 Abd ALSalam(M.A.), Al-sijjāad al-maghwūīi al-hindī, p. 353.

${ }^{83}$ Abd AL-Salam(M.A.), Al-sijjjād al-maghwīlī al-hindī, pp. 287,288.

${ }^{84}$ El-Banna (S.F.), Betel box, pp.141 -142-143\& see pl.1\& pl.23.

${ }^{85}$ Pazobend: A word of Urdu consisting of two sections, the first section (pazo) means arm, while the second

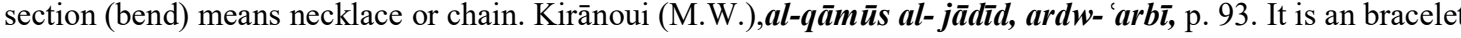
worn in the arm, and is similar in function with antagonists or demalage.Fairoūz el-Din(Maulana), Fairoūz allghāt, p. 151. AL-Shawkī (A.), Tașwīr al-mar'ah fì al- madrasah al- hinddīya, p.283.
} 
Victoria and Albert Museum in London (P1.33). This type is known as "Vanki", due to its Vshaped design, and was commonly produced in southern India ${ }^{86}$ during the Mughal period(P1.33). ${ }^{87}$ In addition to metal artefacts, zigzag decorations were seen on Mughal carpets, similarly to sea waves. ${ }^{88}$

Lobbed arches decorated some of the manuscripts that were produced by the Rajput painting school, specifically in Rajasthan province (P1.29). Arches were used in decorating the Indian Mughal prayer carpets as the upper part of the prayer niche; arches had different shapes, and lobbed arch was one of the most common ones (Fig.9). ${ }^{89}$

It is noticeable that lobbed arches were also used in decorating Mughal Indian prayer carpets, which, due to its use, were void of any birds, animal or human figures. ${ }^{90}$ However, on our two bottles, scenes with human figures occupied the spaces below the lobbed arches, a practice also seen in some of the paintings of the Rajput school.

Using geometric shapes, ${ }^{91}$ especially stars, as a decorative element is thought to be an Indian heritage effect and not a foreign influence. Indeed geometric elements first decorated ancient Indian temples, and later were applied to art objects, especially carpets, and Indian Mughal buildings. $^{92}$

Human figures and floral decorations were used equally in decorating the two bottles, and geometric elements came third. There are no inscriptions on the two bottles. ${ }^{93}$ This reflects the opinion that on Indian Mughal applied objects, inscriptions were used on a limited scale, while it was seen abundantly on residential and religious buildings during the same era. ${ }^{94}$

\section{SECTION 5: A COMPARATIVE STUDY}

The two bottles could be compared with other bottles from the same type preserved in international collections. There are great similarities with, for instance, a bottle with a square base, kept at the Metropolitan Museum of Arts and was published by Jinkins. (P1.34). ${ }^{95}$

\footnotetext{
${ }^{86}$ Krishnan\& Kumar, DanceOf The Peacock,p. 182.

${ }^{87} \mathrm{http}$ ://collections.vam.ac.uk/item/069624/vanki-armlet-unknown. El-Banna (S.F.), Betel box, pl.8.

${ }_{88}$ Abd AL-Salam(M.A.), Al-sijjāid al-maghwūlī al-hind̄̄, pp. 297,298.

${ }^{89}$ The semi-secular arch, pointed arch, keel arch and horse-shoe arches were amongst the types of arches that appeared on the Mughal Indian carpets.

Abd AL-Salam(M.A.), Al-sijjājd al-maghwūlī al-hindī, pp.291,292- Plates 60, 65, 66, 37, 39.

${ }^{90}$ It is worth pointing out that some of the Mughal Indian carpets were plain with no decorations, others had simple decorations of stems and floral elements. Sometimes, a mosque lamp was depicted hanging from the arch of the prayer niche. Prayer carpets from Kashmir were characterised by the abundance of floral decorative elements, apart from one example decorated with a bird. Human and animal figures were not used as decorative elements due to the use of carpets for prayers.

Abd AL-Salam(M.A.), Al-sijjājd al-maghwülī al-hindī, p.336.

${ }_{91}^{1}$ About the geometric elements see: Swarup (Shanti), Mughal Art -A study in Handicrafts,p.30.

${ }^{92}$ Rajab (A.), Monsha'at al-sūltan Shirkhan al-afghany bi madinah dilhī bil-hind, pp.91,92. Abd AL-Salam(M.A.), Al-sijjjād al-maghwūlī al-hindī, p.346.

${ }^{93}$ Indians used Arabic calligraphy, Arabic letters replacing the Urdu ones, after the Muslim conquest during the Umayyad caliphate.. AL-thuluth calligraphy became an important element in decorating the interior and exterior of religious buildings. Inscriptions had various religious and historic content.

AL-Ghabory (Mahmoud), Jamalīyīat al-khat w al-zakhrafa al-arabīyīa, p.65.

Daūūd (M. M.), Al-Kitābāt al- 'arābīyah 'ala al- 'athar al-islāmīyah,p.180.

Rajab(A.), Al- 'imārah al-islāmiyah fì madinat Ajrā bi-al-hind p.299.

${ }_{94}$ El-Banna(S.F.), Betel box (pandan) from Mughal Era in India,p. 150

${ }^{95}$ Jenkins, Islamic Glass: A Brief History, pp. 46-47, ill. fig. 51.
}

- 181 - DOI: $10.36816 /$ shedet.006.09 
Approximately the same height, they were both produced with the blow moulding technique, decorated with gilding and enamel, and originated from Gujarat during the first half of the $12^{\text {th }} \mathrm{H} / 18^{\text {th }}$ century AD.
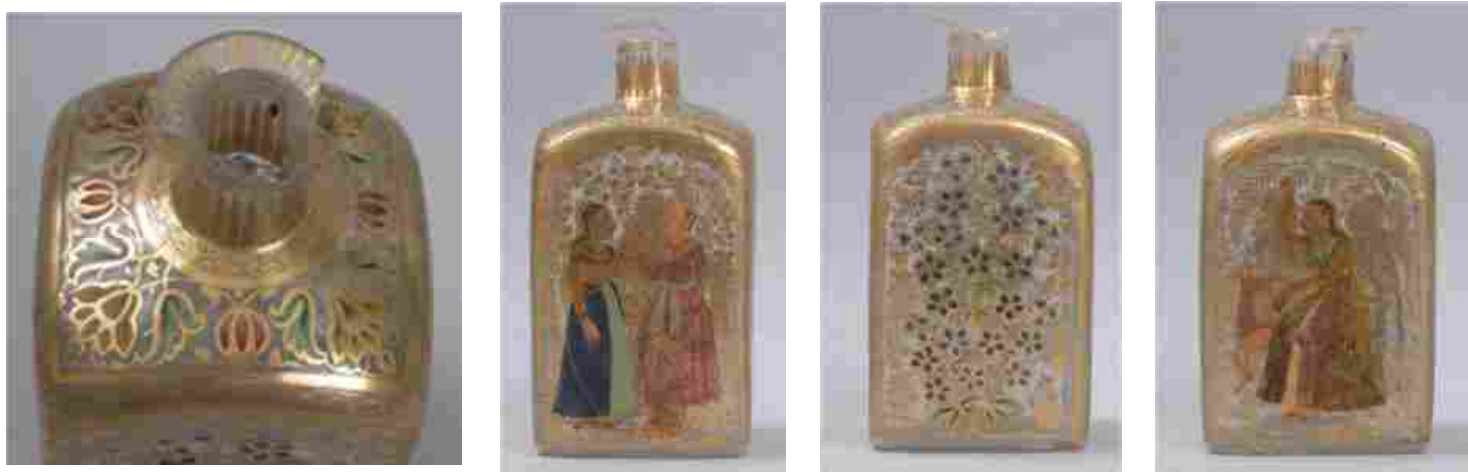

P1. 34. A square enamelled glass bottle with gilded motifs, Metropolitan Museum of Arts. Jenkins-Madina, Marilyn. "Islamic Glass: A Brief History." Metropolitan Museum of Art Bulletin vol. 44, no. 2 (Fall 1986). pp. 46-47, ill. fig. 51.

Two sides are decorated with floral elements and the other two with human figures, including a scene of a man and a woman holding hands (P1.35A), similarly to the scene on the second bottle (P1.35B).

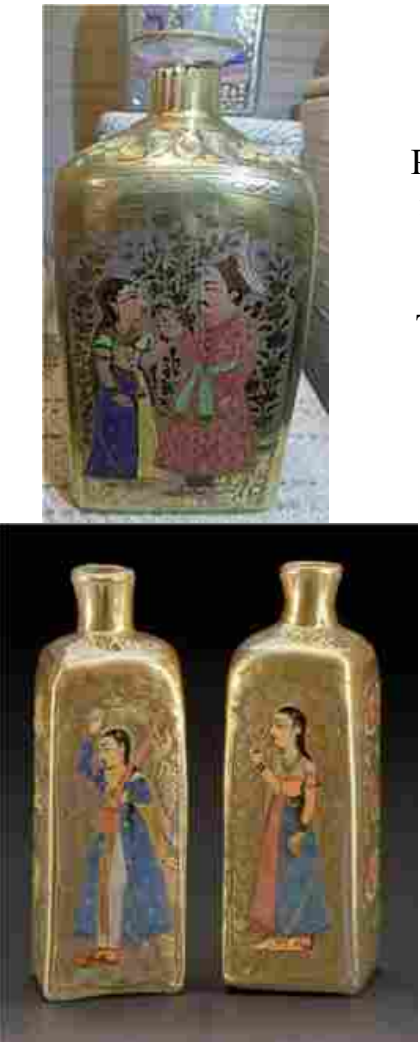

P1.35. a, b. two glass bottles, the first is kept in Metropolitan Museum (Source: JenkinsMadina, "Islamic Glass: A Brief History." Metropolitan Museum, fig. 51)

The second: The second bottle under study, kept in Tareq Rajab Museum.
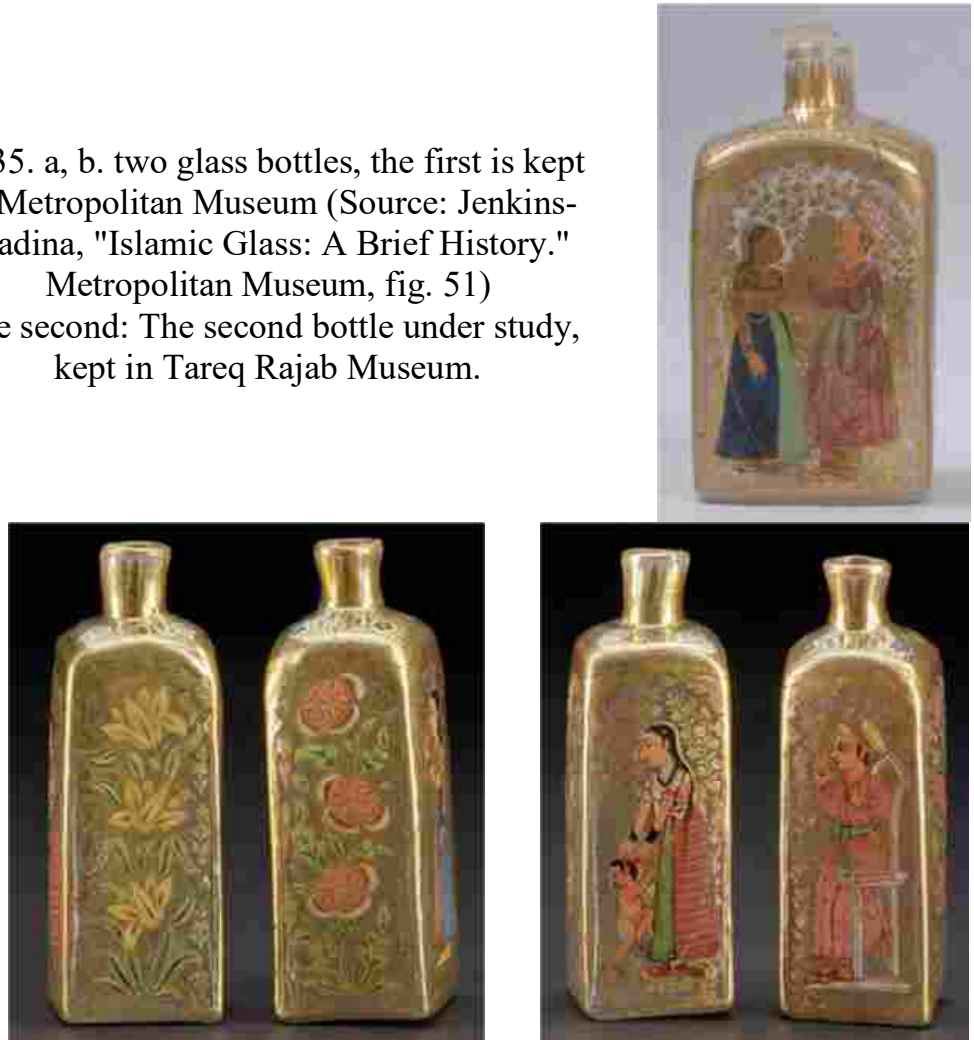

Pl. 36 a, b, c. Two enamelled and gilded glass bottles, decorated with floral ornaments. https://www.masterart.com/artworks/6410/pair-of-mughal-gilt-glass-bottles

https://www.metmuseum.org/art/collection/search/447365?utm_source=pinterest\&utm_medium=pin\&utm_cam paign=loveboard 

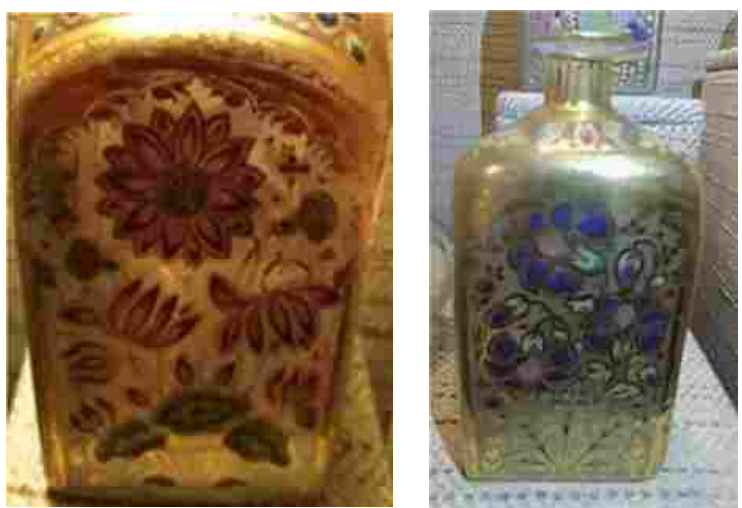

Pl 37 a, b. Two enamelled and gilded glass bottles, decorated with floral ornaments, part of Amir Mohtashimy collection. https://www.masterart.com/artworks/6410/pair-of-mughal-gilt-glass-bottles

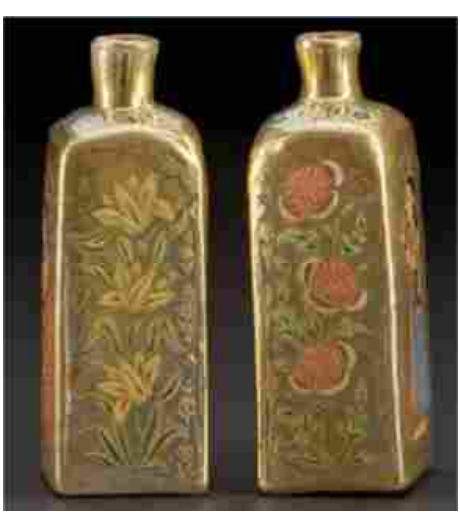

Pl. 37 C, The two bottles under study, decorated with similar floral ornaments.

It is also possible to compare the two bottles with a couple of square base bottles kept in a private collection (Collection of Amir Mohtashemi), for which the same production and decoration techniques were used. The decorative elements are similar as the human figures with Indian features are also wearing traditional Indian costumes (turban, Jama and belt around the waist for the man sitting on a chair) in addition to number of women in different poses. (Pls.36A, B, C). ${ }^{96}$ This bottle has a more elongated shape than the two studied bottles (Pls. 37A, B, C).

Two bottles kept at the Los Angeles County Museum of Art were published by Carboni (Pls. 38 A, B) ${ }^{97}$ There are similarities in the body shape, production and decorative techniques (blow moulding, gilding and enamel), and their size (these two bottles are $13 \mathrm{~cm}$ in height and $6 \mathrm{~cm}$ in width). The decorative elements such as the gilded floral backgrounds and the lobbed arch above the human figures, the chair upon which the lady sits, are nearly identical (Pls. 38A, B, C).

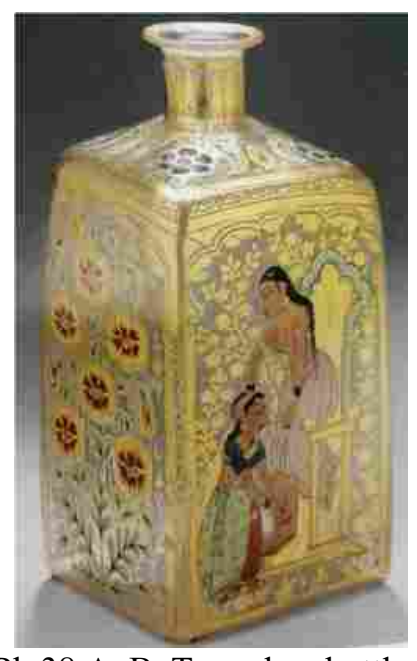

P1..38 A, B. Two glass bottles kept in the Los Angeles County Museum of Art. Carboni, Glass in the Age of the Empires, pls.140-141

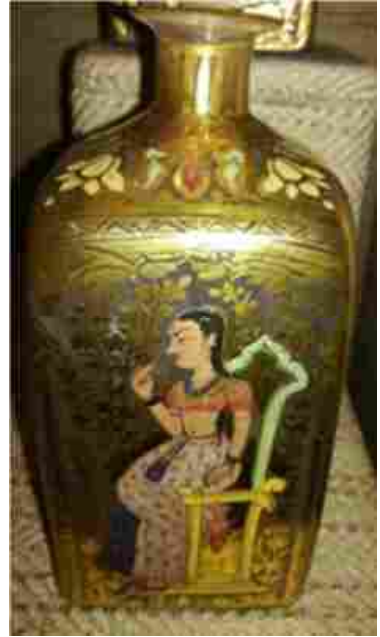

P1 38. C. The second bottle, preserved in Tareq Rajab Museum

${ }_{97}^{96}$ https://www.masterart.com/artworks/6410/pair-of-mughal-gilt-glass-bottles

${ }_{97}$ Carboni (Stefano), Glass in the Age of the Empires, pls.140-141

- 183 - DOI: 10.36816/shedet.006.09 
From this comparison, it is clear that this type of bottles was produced in large numbers, as many examples are kept in several museums. According to a survey, there are 56 bottles of this type known, ${ }^{98}$ to which the two bottles in this study can be added. Moulds with similar dimensions were used to produce most bottles, as they have similar dimensions and shape. Some were produced using a larger mould like those of the Mohtashemi collection. The same decorative pattern was decorating these bottles; most of them have two sides with floral ornaments and two sides with scenes.

\section{CONCLUSIONS}

In this paper, for the first time, two case bottles kept in Tareq Rajab Museum in Kuwait were published and added to the case bottles survey done by Nancy Um.

This type of bottles was one of the most common glass products during the $12^{\text {th }} \mathrm{H} / 18^{\text {th }}$ century AD and may have been produced in large quantity. The term "Case Bottle" was used for this type because of the similarity with the European bottles that where shaped to fit into a wooden case. Also the term Square Bottles is due to its square base and multi-dimensional body. The researcher suggests using the term "Square Prism Bottle" or "Rectangular Prism Bottle" instead of Square Bottle.

It is likely that these bottles preserved perfumes and scented water. This is suggested due to the relation between the scenes on these bottles and perfumes, as well as India's reputation as a producer of perfumes and rose water. The resemblance with the Japanese porcelain bottles which were used for perfumes could support this theory as well.

The technique used in the two bottles is blow moulding within a mould, which produces a more accurate shape. The decoration was done using gilding and enamel, perhaps influenced by Iranian and European designs. The glass products in India during the Mughal period also reflect strong Persian influences not only in the style of the decorations, but also in using enamel which became widespread in Delhi, Kapadavni and Gujarat.

There is uncertainty regarding the place where the two bottles were produced, being either India or Europe. While the chemical analysis shows that it is European, there are accounts that some glass bullions where imported from Europe and were used in producing new objects. The researcher tends to share the opinion of other researchers, especially Carboni, that they were produced in India or Europe, and the researcher believes these bottles were decorated in India due to the decorative technique and style, being similar to the style of Indian Painting schools. Although gilding and enamel were used in several centres in India,

\footnotetext{
${ }^{98}$ Um(Nancy), Nested Containers for Maritime Journeys, pp.199-223. \& see fig7. https://www.journals.uchicago.edu/toc/wes/current

http://www.west86th.bgc.bard.edu/articles/nested-containers/\#easy-footnote-14 According to the survey which was carried out by Nancy Um, and the other places the researcher mentioned while making comparisons; the most prominent places which have bottles similar to our two bottles are: Victoria And Albert Museum, Benaki Museum in Athens and AL-Sabah Collection in Kuwait etc., but the two bottles were not included in her survey. For more information about the bottles preserved in Al-Sabah collection in Kuwait see:

The Al-Sabah collection, Kuwait National Museum, 2001, cat.106, pp.388:90.
} 
the researcher is in favour of the gilding and enamelling for these bottles having been made in Gujarat during the $12^{\text {th }} \mathrm{H} / 18^{\text {th }}$ century AD.

The comparison between the paintings of the Rajput school and the scenes of these two bottles shows that the Rajput school had more influence on the drawings than any other school. This may be due to the fact that this school was widespread in the north-western part of India, a region close to Gujarat where the bottles were decorated. The production timeframe also matches the activity period of this school.

Being decorated with many floral elements in the same proportion than with human figures, these bottles show the fondness of Indian artists in using floral decorations as an influence from the natural environment surrounding them. These floral elements also appeared in other Mughal Indian artefacts. This choice may be associated to the content of these bottles, originally made to store perfumes and scents extracted from plants and flowers. After flowers and human figures, geometric elements came third in the decoration of these bottles, but they were concentrated in the frames, especially a zigzag pattern and lobbed arches. These were common in the decoration of the Rajput School, as well as artefacts such as metal boxes, Indian jewellery known as Pazobend, and the prayer niches on the Indian Mughal prayer carpets. The researcher believes that the geometric ornaments were a local Indian influence rather than a foreign one.

The researcher highlighted the absence of inscription on the two bottles, whether in Arabic or any other language, in comparison with the big number of inscriptions on the buildings that date back to the Mughal period in India.

\section{RECOMMENDATIONS}

The paper recommends that curators of Tareq Rajab Museum attribute a registration number on the two bottles. The researcher suggests TRM/GB1/S10 for the first bottle and the second TRM/GB2/S10. TRM: abbreviation for the museum name, and its own number; Tareq Rajab Museum, GB1: abbreviation for type of the object and its material, and S10: Vitrine number. It is also recommends using LED screen beside vitrine S10 to show the manufacturing techniques and examples of bottles of the same type in other museums or private collections. 


\section{REFERENCES}

- Abbas (M.), Manarah al-Funūn Wa al-hadarah al-īslamīya (in Arabic= Beacon of Islamic civilization and arts), al-matb a al-Dawl īy $\overline{1}$ a, $1^{\text {st }}$.ed, Cairoition, 2010.

- Abd-Aldaym (N. M.), Dirasah liqa 'īdat Narjilh hinīdīya mo'arrakha bimuthaf Gaier Anderson'Beit Al-Kridliya (in Arabic $=$ A study of an Indian Water pipe base dated At the Gayer Anderson Museum "The Beit Al-Kridliya"), Faculty of Archaeology Journal, South Valley University.2007.

- Abd AL-Khalīq (Hana') Al-Zujaj AL-īslamī fi makhazīn wa matahif al-athar fi al-īraq( in Arabic= Islamic glass in archaeological stores and museums in Iraq with a preliminary study of glass), thesis, Baghdad University, 1969.

- Abd Al-kareem(M.), Gujarat bawtakat al-thkafa al-hindīya (in Arabic= Gujarat melting pot of Indian cultures), Sawt al-sharq Journal, (447).Issue, 2005.

- Abdullah (R. A. R), Dīrasah 'laj w sianah al-athar al-zujaj̄̄ȳia al-mūzakhrafa bilmīna w alMumawwaha bildhahab. iatbīkan ala majmo'at mothaf al-fan al-īslamī bil Qahira(in Arabic= Studying the treatment and maintenance of enameled and gold-glazed antiquities, applied to the collection of the Museum of Islamic Art in Cairo), thesis, faculty of Archaeology, Cairo University, 1999.

- Abd AL-Latif (M. A.A.), al-zujaj al-Turk̄̄ al thmanī min khilāl majmo’at matahif al-Qahira Dirasah Atharīȳa Fannīya (in Arabic= Turkish Ottoman glass through collections of Cairo museums "Artistic archaeological study"), PH.D., Faculty of Archaeology, Cairo University, 2004.

- Abd Al-Salam. (M. A.), Al-sijjāad al-maghwūlī al-hindī min khilāl al-Tühaf al-ṭaṭbiqūyah w swar almakhtuwtät (in Arabic= Indian Mughal carpets through the remaining antiques and depictions of the Mughal Indian School"Art archaeological study"), Thesis, Faculty of Arts, Hilwān University, 2013.

- AL-Esh (M. A. A.), al-zujaj AL-Sūrī al-Mumawwah bilmīna w al-dhahab fi al-'sr al-wasīt( in Arabic = Syrian glass camouflaged enamel and gold in the Middle Ages), general directorate of antiquities, Syria, 1966.

- AL-Gawarna (A. M), Al-hind fì zĭl alwīlaya al-īsalmīyia(in Arabic= India under Islamic sovereignty), Hamada for publication and distribution, Erbed, 2006.

- AL-Ghabury (Mahmoud), Jamalīyīat al-khat w al-zakhrafa al-arabīyīa (in Arabic= Aesthetics of Arabic calligraphy and decoration), AL-Mawrid Jounal, (2).Issue, 1980.

- AL-Muhr (R. S.A.), Madaris al-tașwīr al-īslamī fi Iran w al-hind Mondh $\left(10^{\text {th }} H / 18^{\text {th }}\right.$ AD) fi daw majmo'ah mothaf kullīyat al-athar, Jamat al-Qahira(in Arabic=Islamic photography schools in Iran and India from (10 AH / $16 \mathrm{AD})$ until mid $(12 \mathrm{AH} / 18 \mathrm{AD})$ in the light of the collection of the Museum of the Faculty of Archeology Cairo University). Thesis, Faculty of Archeology, Cairo University, 1999.

- AL-nahas (Sh. Y.), AL-'zia' w al-hūlāì al-hindīaya fi 'sr 'batīrah al-maghūl. min khilāl al-Tūhaf alalbaqūyah (923-1247H/ 1526-1857AD) (in Arabic= Indian Fashion and Jewelery in the Age of the Mughal Emperors through the Remaining Collection of Antiquities "Artistic Archaeological Study" (932-1247 / 1526-1857)), thesis, Faculty of Art, Hilwan University, 2017.

- AL-Sawī (Ahmed), AL-Awan̄̄ w al-'dawāt al-manzilīya fī al-hind, Sina'h īslamīya (in Arabic= Glassware and tools in India is an Islamic industry), AL-Itihad $\boldsymbol{A L}$ - ìmaratīya Journal, 2014.

- AL-Shawki (A. A.), Madrasah al-dikn fi al-tașwīr al-Islāmī fí al-Fatrah (895-1098H/1490-1678AD( in Arabic= The Deccan School of Islamic Photography (895-1098 AH / 1490-1678 AD)), PH.D., Faculty of Arts, Ain Shams University 2009.

- AL-Shawkī (A. A), Tașwīr al-mar'ah fĩ al- madrasah al-maghūlia al- hindd̄̄ya( in Arabic= Portraits of women in the Mughal Indian school), Thesis, Ain Shams University, 2005.

- Amina Okada, Indian Miniatures of the Mughal Court, Deke Dusin Berre\&Harry N.Abrahms. Tras, Inc. Publishers, New York, 1992.

- Biswas (A.), Indian Costumes, Ministry of Information and Broadcasting, Delhi, 1985.

- Brijbhushan (J.), The World of Indian Miniatures, distributed in the United States through Harper \& Row, New York,1979.

- Carboni ,Oggetti, Decorate di influsso islamico nella vetraria muranese,tecnica e forma. Atti del primo simposio internayional sull, Arte venegiana el, Arte Islamica, Venzia, dicembre 1986. 
- Carboni(Stefano)\&Whitehouse (David), The Metropolitan Museum of Art, New York, 2001.

- Chand (A.K), Rajasthan miniature painting a review, International journal of advancement in Social Science and Humanity, (1).Vol, (1). Issue, 2016.

- Daūūd (M. M.), al- mishkāwāt al- zujajīya fì al-'sr al-mamlūkī bimothaf AL-fan al-īslamì bilqahīra( IN Arabic= Glass lamps In the Mamluk era), PH.D., Faculty of Archaeology, Cairo University, 1971.

- Daūūd (M. M.), Al-Kitābāat al-'arābīyah 'ala al-'athar al-islāmīyah min al-qarn al-'awal hatāa awākhir al-qarn $12^{\text {th }}$ (in Arabic= Arabic writings on Islamic monuments from the first century until the end of the twelfth century), maktabt al-nahḍah al-masrīyah, Cairo, 1991.

- Dikshit (M.G), History of Indian Glass, Mumbai: Bombay University Press, 1969.

- El-Banna (S. F.), Betel box (pandan) from Mughal Era in India preserved at National Museum of New Delhi "Comparative Artistic Study \& First Published", Shedet 4 (2017), Faculty of archaeology, Fayoum University.

- El-Banna (S. F.), 'Ihya' w muhakat al-qanadīl al-zujajaīya almamlūkīyīa fi al-qarnaīn $13^{\text {th }}-14^{\text {th }} H . / 19^{\text {th }}$ $-20^{\text {th }}$, fī ḍaw' majmo 'a Jadīida līqanadīl Khīdiwī mīsr Abbas Hlmy althanī ( in Arabic= Revival and Simulation of Mamluk Glass Lamps in Al-Qarniyya 13-14H / 19-20M), Faculty of Arts Journal, (64).issue, Assiut University, 2017.

- Eisaa (M. M.),"al-Mar'ah fĩ al-Tașwīr al-Maghūlī al-Hindi w al-Maḥli al-Mu'aṣr Dirāsah liMalāmihhha -Azīā' iha w Zīnatih ( in Arabic= Women in Contemporary Mongolian and Local Indian Photography "A Study of Their Features - Fashions - and Accessories"), Symposium of Islamic Antiquities in the Eastern Islamic World, Faculty of Archaeology, Cairo University, 1998.

- Eisaa (M.M.), Masterpiece of The Islamic Art, Glass Lamps from the Mamluk Period, (7).issue, annual reviewed journal of faculty of archaeology, Cairo University, 1996.

- Farghaly (A. M), AL-Fūnun al-zükhrüfīya fì 'sr al-ṣafawā̄n bī Iran( in Arabic=Islamic decorative arts in the Safavid era in Iran), Madbūlī publications, Cairo, 1990.

- Fairoūz el-Din (M), Fairoūz al-lghāt ( in Arabic= Fayrouz Languages), Fairoūz Publishing, Lahore, 2010.

- Ghazaly (M.M.), Madrasah Rajput fì al-tașwīr al-Hindī $\left(10^{\text {th }} 13^{\text {th }}\right.$ H. $/ 16^{\text {th }}-19^{\text {th }}$ AD). Wa al-ta thîrat al-mahalīya al-Maghūlyīa layha( in Arabic= Rajput School of Indian Photography (10-13H / 1619M) and local and Mongolian artistic influences on it), PH.D., Faculty of Arts, Assuit University, 2018.

- Haidar (N. N) \&Stewart (C. A), Treasures from India-Jewels from the Al-Tahani Collection, Metropolitan Museum, New York, 2014.

- ībrahim (K. A), Lüghāt al-Jasad fí al-qūrān al-karīm (AL- yn wa al-wäjh wa al-yād Namudhajan), dirasah lüghāwīy $\bar{a}($ in Arabic= Body language in the Holy Quran (eye, face and hand model) rhetorical study), Al-Dar al -thakafiya Lil-nashr, Cairo, 2009.

- īsma îl (M.M.S.), Sin 'at al-zūjāj fi Madināt al-Khalīl, Khīlal al-fatrataīn al-mamlūkīya w al'thmanya (in Arabic= Glass industry in the city of Hebron during the Mamluk and Ottoman periods), MA, higher institute of Islamic Archaeology, Jerusalem University,2000.

- Jenkins (M.M). Islamic Glass: A Brief History, the Metropolitan Museum of Art Bulletin, (44).vol, 1986.

- Krishnan (U.R.B) \& Kumar (M.S), Dance Of The Peacock-Jewellery Traditions Of India, India Book House, India, 1999.

- Kiranoui (M.W.), al-qāmī̄s al- jādīd (in Arabic= The new dictionary), ardw-'arbī, Lahore, 1990.

- Losty (J.P.), Indian painting 1590-1880, Olver Forge \& Brendan Lynch, New York, London, 2015.

- Mahir (S. M.), AL-funūn al-īslamīya (in Arabic= Islamic Arts), ḥayah Ummah Lil Kītab, Cairo, 2005.

- Hindawī (R.U), AL- 'nașir al- tașwīrīya dhat al- 'nașir al-hayawañ̄ya fi taṣwīr Makhṭtat almadrasah al-maghūlīya al-hindīya, dirasah atharīy $\bar{a}$ ( in Arabic $=$ Themes pictorial The same animal elements in the depictions of the Indian Mongol school manuscripts, an archaeological artistic study), Thesis, Cairo University, 2009.

- Marzūq (M.A) AL-funūn al- Zukhrufìya al-īslamīya fì al-'sr al- 'thman̄̄ (in Arabic= slamic decorative arts in the Islamic era), The Egyptian General book Authority, $1^{\text {st }}$.ed, Cairo, ,1974. 
- Marzūq (A.M.), Madrasah kashmir fì Tșawīr al-makhṭtat al-īslamīya fĩ al-fatrah min al-qarn (10 ${ }^{\text {th }}$ $13^{\text {th }}$ H. $/ 16^{\text {th }}-19^{\text {th }}$ AD) (in Arabic=School of Kashmir in the depictions of Islamic manuscripts in the period from the century $\left(10^{\text {th }}-13^{\text {th }} H . / 16^{\text {th }}-19^{\text {th }} A D\right)$, PH.D., Faculty of Art, University of Suhaj.2010

- Mohamad (A. A. M), Dirasah atharīyā Fannīya Limagmu 'ah Jadida min al-zujaj AL-Ayub̄̄ Wa almamlūkī bimothaf al-fan al-īslamī bilqahīra (in Arabic= Archaeological artistic study of a new collection of Ayyubid and Mamluk glass at the Museum of Islamic Art in Cairo), PH.D., Faculty of Archaeology, Cairo University,2015.

- Nour (H. M), Tuhaf zujajīya w aukhry ballorīya min 'sr al-Ausrah AL- Alawīyīa, dirasah atharīyā fanniya lnamatdhij min al-qarn $13^{\text {th }} \mathrm{H} / 19^{\text {th }}$ AD Century (in Arabic= Glass and other antiques from the Alawite dynasty Archaeological artistic study of models from the $13^{\text {th }}$ AH $/ 19^{\text {th }}$ AD), Faculty of Arts Journal, (22).Issue, Sohag University, 1999.

- Munaa (S.A, H), fannanūn fĩ marasīm 'bātarah almaghūl fĩ al-hind (in Arabic= Artists at the ceremony of the Mughal emperors in India), maktabat zahara' alsharq, Cairo, 2005.

- Rajab (A.), Al- 'imārah al-islāmiyah fĩ madinat Ajrā bi-al-hind fí 'aṣr 'Abāțirah al-maghūl (in Arabic= Islamic Architecture in Akra, India during the Mughal Emperors), Ph.D., Faculty of Archaeology, Cairo University, 1996.

- Rajab (A.), Monsha'at al-sūltan Shirkhan al- afghany bi madinah dilhī bil-hind (in Arabic= The facilities of the Afghan Sultan Sherkhan in Delhi, India), Symposium of Islamic Antiquities in the Eastern Islamic World, Faculty of Archaeology, Cairo University, 1998.

- Remenih (M), Metals Enamelling, step by step. Guish nash, U.S.A, 1995.

- Sahai (S), Lucknow- 'ndama taqus al- 'mara Tarīkh Madīna ( in Arabic= Lucknow -When architecture tells the history of a city), Sawt al-sharq Journal, (376).Issue, 1995.

- Sharma (L.C), A brief history to Indian painting, satyendra Rastogi Mitra,India,2008.

- Swarup (S), Mughal Art -A study in Handicrafts, Agam Kala Pra Kashan, $1^{\text {th }}$.ed, Delhi, 1996.

- Tiromorti (T.S.), Wilayat Gujarat (in Arabic= Gujarat State), Sawt al-sharq Journal, (310). Issue, 1987.

- Nancy (U), Nested Containers for Maritime Journeys: Tools of Aromatic Diplomacy around the Late Seventeenth- and Early Eighteenth-Century Indian Ocean, journal of decorative arts, the University of Chicago press journals, (25).volume, 2108.

- Ward (R), Glass and brass: parallels and puzzles, (Gilded and enamelled glass from the middle east), British museum, 1998.

- Zebrowski, (M), Gold, Silver and Bronze from Mughal Indian, Alexandria Press in association with Laurence King, London, 1997.

- Zeenut (Z), The Magnificent Mughals, Milo Cleveland Beach, Oxford University Press, 2002.

- Zuhdi (B), Lamha 'n al-zujaz al-qadìm W Rawa" au fì al-mothaf al-watan̄ bidīmishq (in Arabic=A glimpse of ancient glass and its masterpieces in the National Museum of Damascus), Syrian Archaeological Yearbooks, (10).Vol, Damascus, 1960.

\section{WEBSITES}

- https://aawsat.com/home/article/486106/\%D8\%A3\%D9\%82\%D8\%AF\%D9\%85-

- https://www.alittihad.ae/article/62211/2014

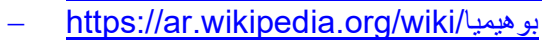

- https://ar.wikipedia.org/wiki/\%D9\%85\%D8\%AA\%D8\%AD\%D9\%81 \%D8\%B7\%D8\%A7\%D8 \%B1\%D9\%82 \%D8\%B1\%D8\%AC\%D8\%A

- http://collections.lacma.org/node/249288

- http://collections.vam.ac.uk/item/069624/vanki-armlet-unknown.

- http://www.britishmuseum.org/research/collection online/collection object details.aspx?

- https://www.journals.uchicago.edu/toc/wes/current

- http://www.west86th.bgc.bard.edu/articles/nested-containers/\#easy-footnote-14

- https://www.metmuseum.org/art/collection/search/447365?utm source=pinterest\&utm mediu $\underline{m}=$ pin\&utm campaign=loveboard

- https://www.masterart.com/artworks/6410/pair-of-mughal-gilt-glass-bottles

- http://trmkt.com/?page id=10.

- http://www.west86th.bgc.bard.edu/articles/nested-containers/\#easy-footnote-1 